NBER WORKING PAPER SERIES

\title{
CIP DEVIATIONS, THE DOLLAR, AND FRICTIONS IN INTERNATIONAL CAPITAL MARKETS
}

\author{
Wenxin Du \\ Jesse Schreger \\ Working Paper 28777 \\ http://www.nber.org/papers/w28777 \\ NATIONAL BUREAU OF ECONOMIC RESEARCH \\ 1050 Massachusetts Avenue \\ Cambridge, MA 02138 \\ May 2021
}

This paper has been prepared for the Handbook of International Economics, Volume V, edited by Gita Gopinath, Elhanan Helpman and Kenneth Rogoff. We thank Angus Lewis and Ritt Keerati for outstanding research assistance. We are grateful to Gita Gopinath, Arvind Krishnamurthy, Matteo Maggiori, Brent Neiman, Ken Rogoff, Adrien Verdelhan, and Pierre Yared for comments. All errors are our own. The views expressed herein are those of the authors and do not necessarily reflect the views of the National Bureau of Economic Research.

NBER working papers are circulated for discussion and comment purposes. They have not been peer-reviewed or been subject to the review by the NBER Board of Directors that accompanies official NBER publications.

(C) 2021 by Wenxin Du and Jesse Schreger. All rights reserved. Short sections of text, not to exceed two paragraphs, may be quoted without explicit permission provided that full credit, including (๑) notice, is given to the source. 
CIP Deviations, the Dollar, and Frictions in International Capital Markets

Wenxin Du and Jesse Schreger

NBER Working Paper No. 28777

May 2021

JEL No. E0,F0,G0

\title{
ABSTRACT
}

The covered interest rate parity (CIP) condition is a fundamental arbitrage relationship in international finance. In this chapter, we review its breakdown during the Global Financial Crisis and its continued failure in the subsequent decade. We review how to measure CIP deviations, discuss the drivers of CIP deviations, and the implications of CIP deviations for global financial markets.

\author{
Wenxin Du \\ Booth School of Business \\ University of Chicago \\ 5807 S. Woodlawn Avenue \\ Chicago, IL 60637 \\ and NBER \\ Wenxin.Du@chicagobooth.edu \\ Jesse Schreger \\ Columbia Business School \\ 3022 Broadway \\ Uris Hall 821 \\ New York, NY 10027 \\ and NBER \\ jesse.schreger@columbia.edu
}




\section{Introduction}

The dollar is the predominant currency in international financial transactions. While the United States accounts for about $15 \%$ of world trade and $25 \%$ of global GDP, the U.S. dollar accounts for about $50 \%$ of cross-border loans and international debt securities, $90 \%$ of all foreign exchange (FX) transactions, $60 \%$ of official FX reserve holdings, and 50\% of trade invoicing (Bank for International Settlements (2020), Maggiori, Neiman and Schreger (2020) and Gopinath and Stein (2018)). The outsized role of the U.S. dollar creates unique challenges for global financial markets.

In particular, the global market for dollar funding is highly fragmented. Many market participants in need of dollars lack access to direct dollar funding from dollar-rich lenders, such as retail and corporate depositors, U.S. money market funds (MMFs), and central bank reserve managers. As a result, financial intermediaries (i.e. large global banks) play a particularly crucial role channeling the global supply of dollars to accommodate the strong demand for dollars. Since the Global Financial Crisis (GFC), balance sheet constraints facing financial intermediaries have tightened considerably, in part due to regulatory reforms on the banking sector. The most salient manifestation of these constraints is the breakdown of the covered interest rate parity (CIP) condition.

CIP is a well-known textbook no-arbitrage condition, which requires that the dollar interest rate in the cash market (the interest rate a borrower pays when directly borrowing

dollars) to be equal to the implied dollar interest rate in the foreign exchange (FX) swap market (borrowing dollars by first borrowing in foreign currency and swapping this foreign funding for dollars). With frictionless markets, if CIP did not hold, an arbitrageur could borrow at the lower rate, lend at the higher rate and earn a sure profit without taking any risk. The incentive to arbitrage away any deviations from these equations would eliminate 
the gap between the two rates, enforcing the CIP condition.

The canonical one-period representation of the CIP condition is given by

$$
1+y_{t, t+1}^{\$}=\left(1+y_{t, t+1}^{i}\right) \frac{S_{t}}{F_{t, t+1}},
$$

where $y_{t, t+1}^{\$}$ is the one-period U.S. interest rate in dollars, $y_{t, t+1}^{i}$ is the one-period interest rate in currency $i$, and $S_{t}$ and $F_{t, t+1}$ are the spot exchange rates and the one-period outright exchange rate defined in units of foreign currency per dollar. Alternatively, CIP can be written in the log-form,

$$
f_{t, t+1}-s_{t}=y_{t, t+1}^{i}-y_{t, t+1}^{\$},
$$

with $s_{t}$ and $f_{t, t+1}$ being equivalent being the log spot and forward exchange rate. In other words, the forward premium, $f_{t, t+1}-s_{t}$, should be equal to the interest rate differential between the two currencies. Prior to the Global Financial Crisis (GFC), this was indeed the case, and CIP held nearly exactly in interbank markets. ${ }^{2}$ The situation has changed dramatically since the GFC. Significant CIP deviations opened up during the peak of the GFC and never went away.

Deviations from CIP represent a major change in global capital markets and the macroeconomy. The breakdown of a key arbitrage relationship in FX markets points to the importance of financial intermediary constraints in the determination of asset prices and the international transmission of shocks. ${ }^{3}$ With major global borrowers dependent on dollar funding, CIP deviations significantly affect the cost of borrowing around the world. In addition, CIP deviations raise a host of important questions about the consequences of post-crisis regulations that caused the emergence and persistence of arbitrage opportunities.

As in Du, Tepper and Verdelhan (2018a), we measure deviations from CIP using the

\footnotetext{
${ }^{2}$ Akram, Rime and Sarno (2008) show that short-lived CIP deviations (from 30 seconds to 40 minutes) were documented, but generally dissipated very quickly, consistent with the efficient market hypothesis. See Levich (2017) for a survey on CIP deviations then and now.

${ }^{3}$ International macroeconomic models with financial frictions are surveyed in Maggiori (2021) in this volume.
} 
cross-currency basis, the difference between the dollar interest rate in the cash market and the implied dollar rate (sometimes referred to as the synthetic dollar interest rate) in the FX swap market. If CIP held, then the cross-currency basis would be equal to zero. In reality, the failure of the CIP condition has become the new normal. In general, the cross-currency basis is negative, suggesting the synthetic dollar interest rate in the FX swap market is higher than the direct dollar interest rate. The basis is highly correlated with the nominal interest rates across currencies and co-moves with global risk factors.

In terms of the drivers of CIP deviations, we begin by exploring how post-crisis financial regulations reduced the supply of dollar funding and hedging services from financial intermediaries by increasing their balance sheet costs. Non-risk-weighted capital requirements, in the form of the leverage ratio requirement, mandate banks to maintain capital against all assets, regardless of their risk characteristics, and thereby restrict the ability of banks to engage in traditional CIP arbitrage (Duffie (2017)). In particular, the traditional "matchedbook" CIP arbitrage requires large banks to borrow dollars in the cash market and lend dollars in the FX swap market. Even though the position is riskless, it still expands the size of bank balance sheet and therefore increases the bank's leverage ratio potentially generating a binding leverage constraint. Binding leverage constraints are also consistent with the existence of a host of other near-arbitrages in the fixed-income market. Beyond the leverage ratio requirement, banks also face additional balance sheet constraints when deploying their existing excess reserves at the Fed to support dollar lending in the FX swap market. These explanations based on the bank balance sheet constraints as a result of the post-crisis regulatory reform differ from the traditional explanations for the failure of the law of one price, including transaction costs, counterparty risk, convergence risk, margin constraints, liquidity, information, and sentiment, such as in Shleifer and Vishny (1997), Garleanu and Pedersen (2011) and Pasquariello (2014).

We next turn to exploring the demand for dollar funding post-crisis. Due to the dollar's reserve currency status and ultra-low interest rates in Europe and Japan post-GFC, the 
demand for dollar funding to fund or hedge dollar-denominated assets remained robust, especially among non-U.S. based market participants. We discuss three main types of clients willing to pay fees to financial intermediaries in the form of the cross-currency basis to obtain dollar funding and hedging services in the FX swap market. First, non-U.S. banks that do not belong to the top-tier of global banks often have difficulty tapping into the direct dollar funding markets or can only do so at a considerably higher cost. Meanwhile, they have access to insured deposits in local currency and thus often choose to raise dollar funding in the FX swap market to finance their dollar-denominated assets (Borio et al. (2016), Ivashina, Scharfstein and Stein (2015), IMF (2019)). Second, institutional investors outside the U.S., such as pensions, insurances and mutual funds, have local currency liabilities and yet choose to invest a significant fraction of their portfolios in dollar-denominated assets. An FX swap arrangement allows them to fund their dollar portfolios and hedge the corresponding currency risk. Finally, non-financial corporates that borrow in multiple currencies may face asymmetric funding costs relative to the local risk-free benchmark because bond markets are segmented by currency (Maggiori, Neiman and Schreger (2020)), and therefore may choose to use the cross-currency swap market to minimize their funding costs (Liao (2020)). We then discuss how central bank swap lines can be used to alleviate funding pressures from various market participants.

Beyond the CIP deviations for benchmark bank rates, we then review what CIP deviations between government bond yields can teach us about sovereign default risk, market segmentation, and convenience yields. Unlike CIP deviations in funding markets, CIP deviations in the government bond market do not necessarily represent an arbitrage opportunity for global banks. A higher synthetic dollar yield on foreign government bonds than the U.S. Treasury yield could capture the perceived relative default risk on the foreign government bonds (Du and Schreger (2016)). Even in the absence of a default risk, CIP may still fail between two government bonds (even if it holds for benchmark bank rates) when investors value the safety and liquidity of one country's bonds more than another, thus driving a 
pricing wedge between the two bonds referred to as the "convenience yield" (Du, Im and Schreger (2018b), Jiang, Krishnamurthy and Lustig (2018)).

Finally, we discuss the new and growing literature on the implications of CIP deviations for exchange rate determination. We review the recent literature regarding the co-movement of the dollar with Libor (Avdjiev et al. (2019)) and government bond CIP deviations (Jiang, Krishnamurthy and Lustig (2018) and Engel and Wu (2018)).

The rest of the chapter is organized as follows. Section 2 discusses CIP measurements, Section 3 presents some stylized facts about CIP deviations, Section 4 discusses the role of bank balance sheet constraints in the supply of dollar funding, Section 5 discusses the demand for dollar funding, Section 6 discusses government bond CIP deviations, and Section 7 discusses the relationship between CIP and exchange rate determination. Section 8 discusses open research questions, and Section 9 concludes.

\section{CIP: Background, Definition and Measurement}

Covered interest rate parity is a no-arbitrage condition that requires the dollar interest rate in the cash market to be equal to the implied dollar interest rate from the FX swap market. Borrowing in the FX swap market means borrowing in foreign currency and then simultaneously entering into an FX swap arrangement to borrow dollars in exchange for foreign currency today and to pay back dollars in exchange for foreign currency at maturity. We first provide a formal definition of the CIP condition and discuss a few measurement issues.

\subsection{CIP Deviation: A Wedge Between Dollar Interest Rates in Two Funding Markets}

Figure 1 shows the cash flow diagram of two types of dollar borrowing. The first type of funding involves the cash market where the borrower directly borrows dollars from a bank 
(e.g. JP Morgan) at the inception of the trade, and repays the principal plus interest at maturity. The loan is unsecured unless the lender requires collateral from the borrower. The most common secured short-term borrowing is a repurchase (repo) contract, against U.S. Treasury bonds as collateral.

In the second type of funding, instead of borrowing dollars directly, the borrower obtains dollar funding in the FX swap market. The borrower first borrows in foreign currency (e.g. Japanese yen), then exchanges yen for dollars with JP Morgan at the spot exchange rate. Simultaneously, the borrower enters into a FX forward contract with the bank to agree on a forward exchange rate to sell dollars at maturity. ${ }^{4}$ At maturity, the borrower fulfills the promise of the forward contract by selling dollars in exchange for yen at the pre-determined exchange rate, and repays the yen principal and interest. Therefore, the FX swap market offers an alternative way to borrow/lend dollars, completely free from exchange rate risk.

The CIP condition requires that the dollar interest rate in the cash market is equal to the synthetic dollar interest rate implied by the FX swap market. In order to understand why CIP fails post-GFC, it is important to first understand the fragmentation of the global dollar funding markets and the important role of financial intermediaries.

Figure 2 illustrates the core players and their interactions in the short-term dollar funding markets. ${ }^{5}$ In particular, large global banks, together with their affiliated repo and FX swap dealers, are at the center of the global dollar funding chain. They raise dollars from cash-rich lenders, such as household and corporate depositors and U.S. MMFs, and then direct the flow of funds to the ultimate dollar borrowers, such other banks, hedge funds, institutional investors, and corporates. Besides getting financing from private cash-rich lenders, the large banks can also draw from their own dollar reserves at the Fed, or enter into the FX swap agreements through central bank FX swap line to support dollar lending to the ultimate borrowers. $^{6}$

\footnotetext{
${ }^{4}$ JP Morgan can on-lend the yen without credit risk by depositing the yen at the Bank of Japan's deposit facility, or lending it in the Japanese repo market, collateralized by Japanese government bonds.

${ }^{5}$ Afonso, Ravazzolo and Zori (2019) provides a more detailed mapping of short-term dollar funding flows.

${ }^{6}$ The diagram focuses on short-term dollar funding. Market participants can rely on capital markets for
} 
Importantly, Figure 2 demonstrates market segmentation in the sense that many ultimate dollar borrowers have difficulty borrowing directly from cash-rich lenders. Large banks act as the indispensable bridge between the two sides. Large banks borrow dollars from the cash-rich lenders at a lower rate and proceed to lend those funds to the ultimate borrowers at a higher rate. The spread between large banks' borrowing rate and lending rate represents an intermediation fee that banks charge in order to provide dollar intermediation services. The CIP deviation is one type of dollar intermediation fee large global banks charge to borrow dollars in the cash market and lend dollars in the FX swap market. As banks face increasing balance sheet constraints that limit their intermediation ability, they seek a higher intermediation fee to compensate for using up precious balance sheet space.

\subsection{Definition of the Cross-Currency Basis}

We now formally define the CIP condition. The multi-period version of the CIP condition is given by

$$
\left(1+y_{t, t+n}^{\$}\right)^{n}=\left(1+y_{t, t+n}^{i}\right)^{n} \frac{S_{t}^{i / \$}}{F_{t, t+n}^{i / \$}},
$$

where $y_{t, t+n}^{\$}$ denotes the $n$-year dollar interest rate in the cash market, $y_{t, t+n}^{i}$ denotes $n$-year interest rate in currency $i, S_{t}^{i / \$}$ denotes the spot exchange rate between the dollar and the foreign currency $i$ (defined as units of foreign currency per dollar), and $F_{t, t+n}^{i / \$}$ denotes the outright forward exchange at time $t+n$, which is locked in at $t$. The left hand-side of the CIP condition gives the cost of borrowing dollars in the cash market, and the right handside gives the total cost of borrowing dollars in the FX swap market by borrowing in foreign currency $i$ and swapping for dollars.

When the CIP does not hold, we follow the market convention by placing a wedge on the right-hand-side of the equation. We define the $n$-year cross-currency basis, or the CIP long-term dollar funding, which is not necessarily intermediated by banks. 
deviation, as $x_{t, t+n}$ in the formula:

$$
\left(1+y_{t, t+n}^{\$}\right)^{n}=\left(1+y_{t, t+n}^{i}+x_{t, t+n}^{i / \$}\right)^{n} \frac{S_{t}^{i / \$}}{F_{t, t+n}^{i / \$}} .
$$

Therefore, in log terms, we have that the cross-currency basis is equal to the difference between the direct dollar rate from the cash market and the synthetic dollar interest from the FX swap market:

$$
x_{t, t+n}^{i / \$}=\underbrace{y_{t, t+n}^{\$}}_{\text {Cash Market Dollar Rate }}-\underbrace{y_{t, t+n}^{i}-\rho_{t, t+n}^{i / \$}}_{\text {FX Swap Market Dollar Rate }},
$$

where $\rho_{t, t+n}^{i / \$}=\left[\log \left(F_{t, t+n}^{i / \$}\right)-\log \left(S_{t}^{i / \$}\right)\right] / n$ is the annualized forward premium of selling foreign

currency $i$ in exchange for the U.S. dollar. A negative cross-currency basis $\left(x_{t, t+n}^{i / \$}<0\right)$ means that the direct dollar interest rate is lower than the the synthetic dollar interest in the FX

swap market, and a positive cross-currency basis $\left(x_{t, t+n}^{i / \$}>0\right)$ means that the direct dollar rate is higher than the synthetic rate.

As we can see in equation 1, the crucial step in calculating the CIP deviation is to measure the annualized forward premium, $\rho$. Conceptually, we can obtain $\rho$ by annualizing the log difference between the outright forward and current spot exchanges. In practice, this requires closely following FX market conventions. We describe the details of FX forward premium calculation in Appendix A.

\section{CIP Deviations for Benchmark Bank Rates}

In this section, we present several stylized facts about CIP deviations for benchmark bank rates. The most commonly used bank rate to test CIP is the Interbank Offered Rate (IBOR), which was used as a proxy for the risk-free rate prior to the GFC. 


\subsection{Pre-GFC and Post-GFC Dichotomy}

Panel A of Figure 3 shows the three-month IBOR cross-currency bases. We can see that CIP deviations were close to zero before the GFC, increased significantly during the GFC, and then remained elevated post-GFC. Panel B shows the bases at the 5-year maturity. The pre- and post-GFC dichotomy is even more stark for the 5-year cross-currency basis.

The first thing to observe is that CIP held remarkably well prior to the GFC. Shortly after the collapse of the Bretton Woods System, there were large interest rate differentials between onshore-offshore markets (Rogoff $(1985))$. Frenkel and Levich $(1975,1977)$ confirm that CIP held exceedingly well among currency pairs in the offshore market. Popper (1993) reaches a similar conclusion for long-term rates based on cross-currency swaps. Obstfeld (1993) and Levich (2017) survey this literature examining interest rate differentials and connecting it to international capital mobility.

During the peak of GFC, the CIP condition broke down, but significant CIP deviation remained post-GFC, even under tranquil financial market conditions. Table 1 reports the mean and standard deviation of Libor-based CIP deviations for the G10 currencies since 2008. It reports these moments for the full sample and for the subset of crisis times. ${ }^{7}$ It is important to note that the IBOR cross-currency basis vis-à-vis the dollar is largely negative for most G10 currencies, with the exception of the Australian dollar (AUD) and the New Zealand dollar (NZD). A negative cross-currency basis means that the direct dollar interest rate from the cash market is lower than the synthetic dollar interest rate. With a negative basis, banks would earn a profit by borrowing dollars in the cash market and lending in the FX swap market.

IBOR rates are imperfect benchmarks for the risk-free rate due to their indicative and unsecured nature. However, CIP deviations exist beyond IBOR. Figure 4 shows that the CIP deviations remain, and even become larger on average, if we use Overnight Index Swap (OIS) rates or repo rates. The OIS rates are indexed to overnight unsecured rate, involving

\footnotetext{
${ }^{7}$ Augustin, Chernov, Schmid and Song (2021) analyze the term structure of CIP deviations in detail.
} 
little credit risk. The repo rates used in the figure are collateralized with government bonds and are free from credit risk. ${ }^{8}$

\subsection{Correlation with Nominal Interest Rates}

There is a strong correlation between the CIP and the level of interest rates in the crosssection. As shown in Figure 5, high-interest-rate currencies, such as the Australian dollar (AUD) and the New Zealand dollar (NZD), tend to have positive cross-currency bases, which implies that the synthetic dollar interest in the FX swap market is lower than the direct dollar interest rate. Conversely, low-interest-rate currencies, such as the euro (EUR) and the Swiss franc $(\mathrm{CHF})$, have very negative cross-currency bases, or higher synthetic dollar interest rates than the direct dollar interest rates. The cross-sectional correlation between the crosscurrency basis and the nominal interest rate level is $90 \%$ since 2008 . We defer the discussion of why the cross-currency basis is correlated with the nominal interest rate to Section 5.2 after we introduce main drivers of CIP deviations.

Furthermore, we note that the direction of the CIP arbitrage is the exact opposite of the classical unhedged FX carry trade, also known as the uncovered interest rate (UIP) trade. To arbitrage CIP deviations, an investor should go long in the low-interest-rate currencies and short in the U.S. dollar, or short in the high-interest-rate currencies such as the AUD and NZD, while fully hedging against the foreign currency risk. For example, the average three-month dollar-yen cross-currency basis is negative 25 basis points post-GFC. To collect this arbitrage profit, the arbitrageur should borrow dollars directly in the cash market for three months, exchange dollars for yen at the spot exchange rate today, and invest in yen for three months. Meanwhile, the investor sells yen forward against dollars to hedge the FX risk using a three-month FX forward contract. In contrast, in a classical unhedged FX carry

\footnotetext{
${ }^{8}$ To address the concern that these benchmark interest rates do not represent the true transaction rates, Anderson, Du and Schlusche (2019) use banks' actual funding rates from the unsecured wholesale funding markets through the issuance of certificates of deposits and commercial paper, and show that more than $95 \%$ of this funding is raised at a cost below the implied dollar funding rate from the dollar-yen swap market by top-tier global banks.
} 
trade (such as in Lustig and Verdelhan (2007), Lustig, Roussanov and Verdelhan (2011) and Hassan and Mano (2019)), an investor goes long in high-interest-rate currencies and short in low-interest-rate currencies, without hedging the FX risk.

To compare profits between the CIP and UIP trades, the average annualized profit on an unlevered three-month CIP arbitrage earns about 20 basis points, whereas the UIP trade earns an average annualized return of about $5 \%$. However, the key difference is that the CIP arbitrage profits are known ex-ante and involve no risk, and therefore, the Sharpe ratio of CIP arbitrage is essentially infinite. In contrast, the UIP trade has an considerable amount of risk, especially during bad times, and has a Sharpe ratio equal to 0.54 based on data from 1994 to 2010 (Hassan and Mano (2019)). The small, but sure profits of CIP arbitrage underscores the importance of using leverage to scale up the return to an attractive level.

\subsection{Co-Movement with Global Risk Factors}

CIP deviations have a strong factor structure. We perform a principal component analysis on the quarterly changes in the five-year cross-currency basis of G10 currencies vis-à-vis the dollar between 2008Q1 to 2020Q3, and find that the first principal component (PC) explains $51 \%$ of the total quarterly variation in the bases. This implies that much of the overall movement in deviations from CIP is driven by common changes in funding conditions, with the various currencies loading heterogeneously on this common variation.

Table 2 displays cross-correlation between the first PC of the five-year basis and other risk factors. First, we see that the first PC is effectively a "level" factor, as it is $96 \%$ correlated with the quarterly changes in the average cross-currency basis across all G10 currencies. Furthermore, the cross-currency basis becomes more negative, which corresponds to higher dollar funding costs in the FX swap market, and generally larger CIP deviations in "bad times" when the global financial conditions are tighter. During these bad times, we generally have a strong broad dollar (Avdjiev et al. (2019)), high VIX, a wide BBB-Treasury spread, low returns on the S\&P index, and negative shocks to the intermediary capital ratio in He, 
Kelly and Manela (2017).

The co-movement between CIP deviations and the global risk factors suggests that the cross-currency basis is also an important barometer of leverage and risk-taking in the global capital markets, highlighting the importance of intermediary constraints (He and Krishnamurthy (2013, 2018)). Larger CIP deviations could reflect a combination of lower supply of dollar funding by financial intermediaries and higher demand for dollar funding by ultimate dollar borrowers, which we will examine in great detail in the next two sections.

\section{CIP Deviations and Bank Balance Sheet Constraints}

\subsection{Supply and Demand Drivers of CIP Deviations}

Why has CIP failed for benchmark interest rates ever since the GFC? To better understand the drivers of CIP deviations, Figure 6 presents a set of supply and demand diagrams for dollar funding in the FX swap market. We have the CIP deviations for bank dollar funding rates plotted on the vertical axis, and the quantity of dollar funding (and hedging services) demanded in the FX swap market plotted on the horizontal axis. Prior to the GFC, the supply of dollar funding and hedging in the FX swap market was perfectly elastic at the point where CIP holds. A flat supply curve at a cross-currency basis of zero prior to the GFC reflects the fact that there was no cost for financial intermediaries to supply dollars in the FX swap market regardless of the quantity demanded. If the CIP deviations were non-zero, the FX swap market maker would borrow dollars at the lower rate and lend dollars at the higher rate in the absence of balance sheet constraints. The force of arbitrage would enforce the CIP condition, regardless of fluctuations in demand for dollar funding.

In the wake of the 2008 crisis, large banks faced increased balance sheet constraints. Therefore, the supply curve for dollar funding became upward sloping, as it became increasingly costly for banks to provide larger quantities of dollar funding and hedging services in the FX swap market. The high balance sheet costs of providing dollar liquidity in the 
FX swap market became a key driver of the persistence of CIP deviations in the post-GFC period. In other words, banks now need to be compensated with a higher CIP deviation in order to be willing to increase their supply of dollar funding in the FX swap market. With an upward sloping supply curve, shifts in the demand for dollar funding (and hedging) can also cause fluctuations in the equilibrium CIP deviation.

In the rest of this section, we focus on the supply-side drivers of CIP deviations by describing the specific balance sheet constraints facing the financial intermediaries. In Section 5, we will discuss the demand-side factors.

\subsection{Non-Risk-Weighted Capital Requirements}

The non-risk-weighted capital requirement, i.e. the leverage ratio requirement, is viewed as the pivotal regulatory constraint for short-term arbitrage as it limits the size of positions that can be taken by global banks (for example, Du, Tepper and Verdelhan (2018a), Duffie (2017), and Boyarchenko et al. (2020)).

Prior to Basel III, the key capital regulation facing large global banks took the form of the risk-weighted-capital requirement, under which banks were required to maintain sufficient capital against risk-weighted assets. Since short-term CIP arbitrage position has little markto-market risk, it has very little risk-weighted capital charge. Under Basel III, in addition

to the risk-weighted capital requirement, the leverage ratio requirement mandates global banks to also maintain at least sufficient capital against all assets regardless of their risk characteristics. In particular, the Basel III leverage ratio rule requires that

$$
\text { Leverage Ratio }=\frac{\text { Tier } 1 \text { Capital }}{\text { Total Exposure }} \geq 3 \% \text {, }
$$

where "Tier 1 capital" includes equity and retained earnings and "Total Exposure" includes all assets, derivatives exposure, and certain off-balance-sheet positions.

A more binding leverage ratio requirement under Basel III can explain the persistence 
of CIP deviations and other bank-intermediated arbitrages that rely on bank balance sheet sheet space. Non-U.S. banks did not face the leverage ratio requirement prior to Basel III. For U.S. banks, the supplementary leverage ratio requirement increased the leverage ratio requirement from 3\%, prior to Basel III, to the current level of 5-6\% for U.S. banks, making the leverage ratio requirement more binding. The canonical CIP arbitrage requires borrowing dollars in the cash market and lending dollars in the FX swap market, which expands the size of the bank balance sheet and tightens the leverage ratio requirement. In Figure 6 , these non-risk weighted capital requirements transform the dollar funding supply curve from being flat to upward sloping, as the lenders (global banks) now need to be compensated for using up limited space on their balance sheets.

In addition to the leverage ratio requirement, large global banks also face an additional capital surcharge for being global systemically important banks (GSIBs). The GSIB capital surcharge takes five components, including size, inter-connectedness, substitutability (share of wholesale funding in the U.S. implementation), complexity, and cross-jurisdictional activities. A plain-vanilla CIP arbitrage position, where the cash leg is funded by borrowing dollars in the U.S. wholesale funding market (e.g. repos, commercial paper, or certificates of deposit), and the FX swap lending leg is done with respect to a non-U.S. counterparty in Europe or in Japan, increases every single dimension of the GSIB surcharge score.

The large CIP deviations on quarter-ends and year-ends offer a clean illustration of the impact of the leverage constraint and the GSIB surcharge on short-term CIP deviations. In most non-U.S. jurisdictions, the Basel III leverage ratio is calculated based on the quarterend snapshot of bank balance sheets. In addition, the GSIB-surcharge score is calculated on the year-end snapshot of bank balance sheets in almost all jurisdictions. ${ }^{9}$ As a result, many large non-U.S. banks shed balance-sheet intensive dollar intermediation and CIP arbitrage positions on quarter-ends in order to report a better leverage ratio. Therefore, CIP arbitrage

\footnotetext{
${ }^{9}$ For U.S. banks, the leverage ratio is calculated using daily average assets within the quarter, and two sub-components of the GSIB score (size, wholesale funding) are also calculated based on the average daily balance sheets.
} 
positions that show up on quarter-end balance sheets are associated with significantly higher profits to justify the higher shadow cost associated with more scarce quarter-end balance sheet capacity.

Figure 7 plots the quarter-end dynamics of short-term CIP deviations for the dollar-yen basis, updating a figure from Du, Tepper and Verdelhan (2018a). We can see that the oneweek CIP deviations spike exactly one-week before the end of the quarter, stay elevated for the rest of the quarter, and then normalize after the quarter ends. Similarly, the one-month CIP deviations spike exactly one-month before the end of the quarter, and stay high until the quarter-ends. Among all the quarter-ends, the year-ends are associated with higher CIP deviations due to the additional balance sheet constraint associated with the GSIB surcharge score disclosure in recent years (Cerutti, Obstfeld and Zhou (2019)). The one-week dollar-yen CIP deviation reached an annualized 860 basis points at the 2017 year-end.

Table 3 summarizes the size of the quarter and year-end effects for annualized dollar-yen CIP deviations. The average one-day jump is equal to 148 basis points for the one-week deviation and 40 basis points for the one-month deviation across all quarter-ends since 2015 as the contracts begin to show up on the quarter-end balance sheet. The year-end effect is illustrated by a 20 basis point discrete jump on average in the three-month CIP deviation as the contracts begin to show up on the year-end balance sheet. ${ }^{10}$

Cenedese, Corte and Wang (2020) provide further evidence that the leverage ratio requirement affects CIP deviations. They demonstrate that dealers who face a tighter leverage ratio constraint due to a change in regulation charge their clients a significantly higher intermediation fee than the unaffected dealers do. Andersen, Duffie and Song (2019) provide a very useful framework to analyze why shareholders are not willing to raise capital in order to exploit the CIP arbitrage. The key insight is that the debt overhang problem dilutes the benefits of the arbitrage profits on shareholders when banks' funding costs are high. ${ }^{11}$

\footnotetext{
${ }^{10}$ In addition to tighter balance sheet constraints, Wallen (2020) show that the quarter-end spikes in CIP deviations also in part reflect dealers' market power.

${ }^{11}$ Duffie (2017) calibrates a simple numerical example for a large U.S. bank to illustrate that the CIP deviation has to be at least 37 basis points to compensate the shareholders for the dilution effect.
} 


\subsection{Constraints on the Composition of Bank Balance Sheets}

Since the GFC, large asset purchases by the Federal Reserve created a large amount of excess reserves for banks. It is even more puzzling to understand why CIP deviations exist in an environment with high levels of excess dollar liquidity. In particular, why can't large global banks use their excess reserves at the Fed to support more lending in the FX swap markets? Correa, Du and Liao (2020) refer to the use of excess reserves to support short-term liquidity provision as "reserve-draining intermediation". The persistence of CIP deviations despite large excess reserves point to additional balance sheet considerations beyond the Basel III regulatory metrics.

Figure 8 calculates the overnight CIP deviation for central bank deposit rates between the Fed and other major central banks (Correa, Du and Liao (2020)). Global banks with access to a deposit facility at the Federal Reserve, the Bank of Japan (BOJ), and the European Central Bank (ECB) earn consistently higher returns by depositing their excess reserves at the BOJ or the ECB on an FX swapped basis than they would by depositing at the Fed, despite negative central bank deposit rates being offered by the BOJ and the ECB.

From the perspective of the large global banks, shifting dollar reserves from the Fed toward "swapped" dollar reserves at the BOJ and the ECB does not worsen a bank's Basel III leverage ratio, or the liquidity coverage ratio ratio. This is because the change in the composition of reserves does not increase the size of the bank balance sheet. Furthermore, all reserves at major central banks are considered high quality liquid assets for the Basel III liquidity coverage ratio calculation. Therefore, if banks were only constrained by these Basel III regulatory ratios, then they should increase their demand for the BOJ and ECB deposits while reducing their deposits at the Fed, shrinking the IOER CIP deviations to zero. A higher demand for swapped ECB and BOJ reserves effectively leads to more dollar lending in the FX swap market.

Banks may prefer to hold dollar reserves, as opposed to holding swapped ECB and BOJ reserves (and effectively lending dollars in the FX swap market), in part due to addi- 
tional balance sheet constraints regarding intraday liquidity and the distribution of liquidity across entities and jurisdictions (Correa, Du and Liao (2020) and Copeland, Duffie and Yang (2020)). First, reserves at the Fed offer the best intraday dollar liquidity, as they can be used to settle dollar transactions. A swapped BOJ/ECB deposit only offers overnight liquidity in dollars, as the dollar is locked by the overnight FX swap, and cannot be used to fulfill liquidity demand during the day. The intraday liquidity advantage of reserves also showed up prominently during the repo market turmoil in September 2019.

Second, a lower reserve level at the Fed and higher reserve levels at the ECB and BOJ would change the distribution of dollar liquidity across entities and geographies. From the perspective of the U.S. banks, this is a particular concern given that U.S. banks are required to maintain a sufficient level of liquidity in entities and jurisdictions for resolution planning purpose, as part of the Resolution Liquidity Adequacy Positioning (RLAP) rules. RLAP calculations not only take into account localized stresses but also the prospect of local regulators outside the United States requiring incremental liquidity in their jurisdiction (ring-fencing). Therefore, more dollar lending in the FX swap market could mean more liquidity trapped outside the U.S. jurisdictions, which makes the RLAP rules more binding.

\subsection{Co-movement with Other Near-Arbitrage Spreads}

Given financial intermediaries play a central role in many asset markets, post-crisis regulations should have effects in many asset prices, beyond CIP arbitrages. Most prominently, the existing literature has documented several important fixed-income near-arbitrage opportunities, including the IOER-Fed Funds arbitrage (Banegas and Tase (2020)), the bond-CDS basis (Bai and Collin-Dufresne (2019)), the negative swap spread (Jermann (2020), Klin-

gler and Sundaresan (2019)), the Treasury cash-futures basis (Fleckenstein and Longstaff (2020)), the mortgage dollar rolls (Song and Zhu (2019)), the Refcorp-U.S. Treasury spread (Longstaff (2004)), and the KfW-German bund spread (Schwarz (2019)). These arbitrage activities either only emerged post-GFC or have become much larger post-GFC. 
Banks play a key role in arbitraging these bases, and therefore, bank balance sheet constraints should affect all of these near-arbitrages (Boyarchenko et al. (2020)). Du, Hébert and Huber (2019) confirm a strong co-movement in these near-arbitrages, with the first principal component explaining about $53 \%$ of the total variation. In addition, this first principal component has a $68 \%$ correlation with the average Libor CIP deviations for G10 currencies vis-à-vis the dollar (Figure 9).

Despite the strong comovements with other arbitrage bases, deviations from CIP measure offshore dollar funding conditions, which can directly affect the demand for dollardenominated assets and the currency choice of corporate issuance in a way distinct from the other asset prices. In Section 5, we will outline how fluctuations in CIP deviations affect cross-border funding and investment decisions.

\subsection{Constraints Facing Non-Bank Market Participants}

So far, we have discussed balance sheet constraints facing large global banks engaging in dollar intermediation activities and earning the CIP deviations. The natural question to ask is whether non-regulated entities can take over the role of global banks and become large dollar liquidity providers.

The FX swap market is very dealer-centric. The bulk of trade in FX swaps is intermediated by roughly 15 large dealers that are affiliated with large bank holding companies. Furthermore, top banks have ready access to wholesale funding markets, which makes them the most natural arbitrageurs for CIP deviations. Given sticky lending and trading relationships, there are significant barriers for non-bank-dealers to increase their role in the FX swap market.

Furthermore, levered investors such as hedge funds rely on banks to obtain funding for arbitrage. Therefore, the constraints on the bank balance sheets would spillover to these nonregulated entities, increasing their funding costs and reducing their ability to participate in those arbitrage opportunities (Boyarchenko et al. (2020)). Going back to the global dollar 
funding chain depicted in Figure 2, large banks borrow dollars directly from cash-rich lenders and levered investors borrow from large banks. The funding cost differential for large banks and levered investors can be substantial. Taking the repo market as an example, large banks borrow repos from MMFs in the triparty repo market and then lend to smaller banks in the General Collateral Funding (GCF) repo market and to hedge funds in the bilateral repo market. The bilateral repo market is more opaque with less readily available data, but we know that the spread between the overnight GCF and triparty repo rate is about 10 basis points in normal times, with increases of about 30 basis points on average at quarterends (Copeland, Davis, LeSueur and Martin (2012, 2014); Correa, Du and Liao (2020)). A significant part of CIP arbitrage profit would be eroded by the higher funding cost.

As opposed to levered investors, real-money investors with large dollar endowments can potentially play a bigger role in lending dollars in the FX swap markets. In particular,

foreign exchange reserve managers can increase portfolio yields by swapping yen, euro and Swiss franc assets into dollars, effectively lending dollars in the FX swap market. For example, Debelle (2017) discusses that the Reserve Bank of Australia actively swapped Japanese government bonds into U.S. dollars, which offered significantly higher returns. The likely constraints facing real-money investors to scale up their CIP arbitrage position include rather rigid investment mandates, aversion to benchmark tracking errors, and reluctance to maintain large derivatives position. However, systematic studies on these arbitrage activities by real-money investors do not exist to our knowledge and understanding the precise constraints non-banks face is an important area for future research.

\section{Demand for Dollar Funding and Hedging Services}

The persistent CIP deviations reflect not just financial intermediaries' constraints in supplying dollars, but also a steady client demand for dollar funding and hedging services in the FX swap market. With regulations causing the supply curve for dollar funding to slope up, 
fluctuations in the demand for dollar funding will now lead to changes in the magnitudes of CIP deviations (Figure 6). Financial intermediaries are collecting the CIP deviations as an intermediation fee, but who is paying them this fee? We first discuss the main clients demanding dollar funding and hedging services in the FX swap market. We then review the link between dollar funding and hedging demand and the interest rate differential across countries. Finally, we examine the role of the central bank swap line in meeting offshore dollar funding demand during major global funding crunches.

\subsection{The Demand Side of the FX Swap Market}

We discuss three main client types demanding FX swaps: banks, non-bank financial institutions, and corporate issuers.

\subsubsection{Banks}

The first set of FX swap users are banks, with non-U.S. banks being particularly important. These banks demand dollar funding and hedging services in the FX swap market in order to manage currency risk between their on-balance-sheet assets and liabilities in order to minimize currency mismatch. Any unhedged FX exposure can potentially lead to large swings in banks' net worth and carry significant regulatory penalties.

Why would non-U.S. banks borrow dollars in the FX swap market as opposed to directly borrowing in the cash market? Market access to cash funding markets can be an important barrier. Non-U.S. banks generally do not have access to steady dollar deposits and rely more on wholesale funding than U.S. banks. For example, the U.S. MMFs account for the bulk of the unsecured and secured wholesale funding lent to non-U.S. banks, but the U.S. MMFs generally only lend to top-tier global banks and maintain strict requirements in terms of counterparty risk limit and stable lending relationships (Chernenko and Sunderam (2014)). Many smaller non-U.S. banks do not have access to MMF funding and therefore need to choose between cash dollar funding from large banks or synthetic dollar funding in the FX 
swap markets. As shown in Rime, Schrimpf and Syrstad (2019), banks with lower credit ratings may find it cheaper to borrow from the FX swap markets than to borrow directly from large banks. Even for top-tier global banks, their funding from MMFs can also dry up quickly during periods of financial distress, which can then cause them to rely more on dollar funding from the FX swap markets (Ivashina, Scharfstein and Stein (2015)). One notable exception to the dollar shortage for the non-U.S. banks is that the Australian banks often tap offshore dollar funding and swap back to the Australian dollar in response to low domestic savings and attractive domestic investment opportunities (Borio et al. (2016)).

The geography, risks and vulnerability associated the dollar funding model of non-U.S. banks are thoroughly examined in cross-country studies based on the BIS international banking statistics, such as McGuire and Von Peter (2009); Aldasoro and Ehlers (2018); Barajas et al. (2020); Aldasoro et al. (2021). Abbassi and Bräuning (2020) examine FX hedging decision for German banks using micro-level data on FX derivatives.

\subsubsection{Non-Bank Financial Institutions}

Second, non-bank financial institutions also demand large amounts of dollar funding and hedging services. This is particularly true for long-term institutional investors based in Europe and Japan. The negative local yield environment prompted European and Japanese investors to invest abroad, particularly in dollar-denominated assets which offered higher nominal yields. However, these non-U.S. institutional investors, such as pensions and insurance companies, typically have their liabilities in local currency. Therefore, they would need to fund their dollar purchases today and hedge the currency risk by selling dollars in the forward market, equivalent to borrowing dollars in the FX swap market. Liao and Zhang (2020) and Greenwood, Hanson, Stein and Sunderam (2020) discuss the hedging demand channel in determining the spot exchange rate and CIP deviations.

Systematic studies that disentangle FX hedged vs. unhedged flows into U.S. fixed income markets do not yet exist. However, the total amount of dollar hedging demand from institu- 
tional investors can be very sizable. For example, the top eight Japanese lifer insurers alone hold about $\$ 400$ billion USD-denominated assets and have a hedge ratio about $50 \%$ in 2019 , generating $\$ 200$ billion demand for dollar hedging in the dollar-yen FX swap market (Goto and Miyairi (2019)). Setser and S.T.W (2019) conduct a forensic analysis on the Taiwanese life insurance companies and estimate about $\$ 250$ billion FX demand in the USD-Taiwanese dollar FX swap market.

\subsubsection{Corporate Issuers}

Corporate issuers are important users of cross-currency swaps as they seek to minimize their funding costs and hedge other risks. As shown in Liao (2020), corporate borrowers may face different funding costs in bond markets across different currencies. Maggiori, Neiman and Schreger (2020) and Burger, Warnock and Warnock (2018) demonstrate that corporate bond markets are segmented by currency, with investors having portfolios that are dramatically overweight with bonds in their local currency, a phenomenon dubbed "home-currency bias." Because of this segmentation in international bond markets, ${ }^{12}$ firms face a dramatically different investor base depending on the currency in which they borrow. Firms can thereby potentially reduce their funding costs without taking on any currency risk by borrowing in a foreign currency and swapping the proceeds back into their local currency. ${ }^{13}$

Suppose a firm would like to package any foreign currency borrowing with a hedge in a way that minimizes its all-in cost of borrowing. If capital markets were perfectly integrated and frictionless, such borrowing choice would be irrelevant: if CIP held within the firm for any currency composition of borrowing, the all-in cost would also be the same across all funding currencies. If instead, however, investors are segmented by currency, this suggests a rationale for firms to engaged in hedged-foreign currency borrowing to lower their borrowing

\footnotetext{
${ }^{12}$ Theoretical frameworks featuring segmentation by currency include Chien et al. (2015), Dou and Verdelhan (2015), and Gabaix and Maggiori (2015). Lustig and Verdelhan (2019) demonstrate the limits of models featuring incomplete markets without segmentation.

${ }^{13}$ These motives are quite distinct from the motives for unhedged foreign currency borrowing, such as those explored in Bruno and Shin (2017), Bruno and Shin (2020), and Salomao and Varela (2018).
} 
costs. A consequence is that if firms want to minimize their borrowing costs without taking on currency risk, they may prefer to issue a bond where it is cheapest on the FX-hedged basis and then use the cross-currency swap market to achieve the desired currency exposure. As a result, issuer-specific CIP deviations predict corporate issuance, as shown in Liao (2020). Figure 10 shows that when it is more expensive to issue in euros and then swap into dollars than issuing directly in dollars, we observe more dollar debt issued by euro-area firms than euro debt issued by U.S. firms. ${ }^{14}$

McBrady and Schill (2007) present evidence that such opportunistic hedged foreign currency borrowing reduces borrowing costs by 4 to 18 basis points. However, as shown in Maggiori, Neiman and Schreger (2020), it is only a small set the largest firms that are potentially able to reduce their funding costs through hedged multi-currency issuance. There is a large size-dependent selection pattern in bond issuance, with the largest firms borrowing in multiple currencies while the vast majority of firms only borrow in a single currency.

There are a number of open questions about the frictions non-financial corporate face in engaging in hedged borrowing to lower their funding costs. For instance, little is known about any sort of fixed costs firms pay to borrow in foreign currency or whether the frictions are more on the bond issuance side or the currency hedging side. More generally, understanding how market segmentation by currency in bond markets affects the firm's optimal capital structure is an area with a need for more future research. ${ }^{15}$

\subsection{Dollar Funding Demand and Interest Rates}

The funding/hedging demand channel can help explain the relationship between the crosscurrency basis and interest rates we observe in Figure 5. The search for yield motive prompts clients in low-interest-rate countries (e.g., Japan, euro area, and Switzerland) to go long in

\footnotetext{
${ }^{14} \mathrm{CIP}$ deviations for individual corporate issuers could be the opposite sign of the CIP deviations faced by intermediaries based on Libor or OIS rates due to differences in credit conditions facing top-tier global banks and risky corporate issuers. Therefore, the hedging demand from multi-currency issuers for funding cost arbitrage could push the Libor/OIS CIP deviations even wider.

${ }^{15}$ Alfaro, Calani and Varela (2021) examine the use of currency derivatives by firms in Chile to hedge their cash-flow exposure.
} 
high-interest-rate currencies (e.g. the U.S. dollar and the Australian/New Zealand dollar) to earn the interest rate carry. This cross-currency investment demand generates dollar funding and hedging demand, which has to be provided by financial intermediaries. Financial intermediaries fund dollars in the cash market and lend dollars in the FX swap market to fulfill the client demand. Since the low-interest-rate currencies on a hedged basis offer higher synthetic dollar yields than high-interest-rate currencies, financial intermediaries earn CIP deviations as an intermediation fee to justify using up precious balance sheet space. Consistent with the hedging demand channel, Liao and Zhang (2020) link the cross-country pattern of CIP deviations to net U.S. dollar asset holdings.

Through the lens of the supply and demand diagrams in Figure 6, an unexpected widening of the nominal interest rate between the U.S. and foreign currency shifts the demand curve to the right, widening the CIP deviations or the cost of funding and hedging dollars for offshore investors. The empirical literature confirms that shocks to the nominal interest rate arising from monetary policy surprises lead to variations in CIP deviations (Du, Tepper and Verdelhan (2018a), Viswanath-Natraj (2020), Keerati (2020), and Dedola et al. (2021)). In particular, unexpected tightening in the U.S. monetary policy and unexpected accommodation in foreign monetary policy lead to a widening of the CIP deviations of the foreign currency via-à-vis the dollar. ${ }^{16}$ Furthermore, Iida, Kimura and Sudo (2018) show that the difference in the slope of the yield curve between the U.S. and foreign countries are also shown to be correlated with CIP deviations in time series. A steeper U.S. yield curve and a flatter foreign yield curve increase the demand for dollar-denominated assets for FX-hedged banks and investors, which increase the demand for dollar funding and hedging in the FX swap market.

The response of the cross-currency basis to monetary policy shocks has important implications for the external transmission of the U.S. monetary policy. Prior to the GFC, when the CIP condition held, the offshore dollar funding conditions in the FX swap market were

\footnotetext{
${ }^{16}$ Miranda-Agrippino and Rey (2020), Bekaert et al. (2013), and Kalemli-Özcan (2019) consider the transmission of U.S. monetary policy into global risk and asset prices.
} 
nearly identical to the cash markets. Post-GFC, a negative cross-currency basis makes the offshore dollar funding condition tighter than the cash market funding condition, gauged by traditional indicators such as the Libor-OIS spread. Furthermore, unexpected U.S. monetary policy tightening pushes the cross-currency basis more negative, further tightening the offshore dollar funding conditions. Amador et al. (2020) present a framework with financial intermediaries where CIP deviations emerge endogenously when interest rates are at the zero lower bound.

\subsection{The Role of Central Bank Swap Lines}

The surge in dollar demand and the significant cutback in dollar funding supply during crises times result in acute global dollar funding crunches. Large spikes in CIP deviations correspond to elevated dollar funding and hedging costs for offshore market participants, and pose considerable risk to financial stability. The inability to roll-over short-term dollar funding and hedging can lead to fire sales of dollar-denominated assets and propagate financial distress to longer-maturity assets. In Figure 6, this shift in the supply of dollar funding in crises would be captured by the counterclockwise rotation of the supply curve in the middle panel, leading to a spike in the CIP deviation at a lower quantity of funding. If demand shifts outward as well, CIP deviations will increase further. Central bank swap lines were established between the Fed and other major central banks to backstop the global dollar funding markets.

The mechanics of the central bank swap lines are as follows. Local banks in countries with a swap line agreement with the Fed can borrow dollars from their respective central banks by pledging eligible collateral in their local currency. Their central banks then tap the central bank swap lines to borrow dollars from the Fed against their local currencies. Before the COVID pandemic, the Fed maintained standing swap line facilities with five major central banks: Bank of Canada, the Bank of England, the European Central Bank, the Bank of Japan, and the Swiss National Bank. During the pandemic, additional temporary swap line 
agreements were established between the Fed and additional central banks. ${ }^{17}$ Since October 2008, the pricing of the dollar funding via the swap line is set at a fixed rate over the ongoing OIS rate. The spread over the OIS rate was initially set to be 100 basis points during the peak of the GFC, and was lowered to 50 basis points in November 2011 to address the funding strain induced by the European Debt Crisis, and was again lowered to 25 basis points in March 2020 in response to the COVID pandemic. ${ }^{18}$

Figure 11 shows the central bank swap line outstanding since 2008, together with the one-week implied dollar funding rates from the central bank dollar swap line and from the dollar-yen FX swap market. ${ }^{19}$ The central bank swap line was heavily drawn during the three most recent crises. The peak swap outstanding was about $\$ 580$ billion at the height of the 08-09 global financial crisis, $\$ 110$ billion at the peak of the European debt crisis, and $\$ 450$ billion during the COVID pandemic. Overall, central bank swap lines are found to be quite effective in restoring market conditions in the global dollar funding markets (Goldberg, Kennedy and Miu (2010); Bahaj and Reis (2018, 2020); Cetorelli, Goldberg, Ravazzolo et al. (2020)). The swap line maturities vary from one week to 84 days. One distinct feature of the swap line take-up during COVID is that there is a higher share of demand for the threemonth contracts, which reflects the increasingly important role of institutional investors in demanding dollar hedging services. ${ }^{20}$

Outside these crisis episodes, swap line usage was very low, as the FX swap rate from the private FX swap market is generally lower than the rate from central bank swap lines outside quarter-ends. Despite the near-zero usage, the existence of the swap line as a global

\footnotetext{
${ }^{17}$ For example, in response to the dollar funding crunch during the Covid-pandemic, another nine central banks were added to the swap line agreements on a temporary basis, including the Reserve Bank of Australia, the Banco Central do Brasil, Danmarks Nationalbank (Denmark), the Bank of Korea, the Banco de Mexico, the Reserve Bank of New Zealand, the Norges Bank (Norway), the Monetary Authority of Singapore, and the Sveriges Riksbank (Sweden).

${ }^{18}$ For detailed analyses of disruptions in the dollar funding market during the March 2020 market turmoil, see Avdjiev, Eren, McGuire et al. (2020) and Eren, Schrimpf and Sushko (2020).

${ }^{19}$ The modern-day central bank swap lines have historical predecessors going back to the 1960s. Major central banks and the BIS used swaps to manage eurodollar liquidity conditions (McCauley and Schenk (2020)).

${ }^{20}$ The most common FX hedging practice for institutional investors is to roll over short-term FX forwards on the one-month or three-month basis.
} 
dollar liquidity backstop helps anchor pricing in the private FX swap market in normal times. During the quarter-ends in recent years, the central bank swap line pricing is on average 150 basis points cheaper than the dollar-yen FX swap market. However, the total take-up at the swap line was only $\$ 2$ billion on average. The low take-up of central bank swaps during normal times when it is economically attractive to do so is in part due to the stigma from tapping the central bank facilities and moral suasion from central banks to use the central bank swap line as a liquidity backstop, as opposed to providing regular daily funding.

The Fed dollar swap line is only available to a very limited set of central banks. For foreign central banks without swap line agreements with the Fed, the recently Fed established a new temporary liquidity facility, the Foreign and International Monetary Authorities (FIMA) repo facility in March 2020, which allows foreign central banks to pledge U.S. Treasury securities in order to borrow dollar funding. However, the FIMA repo facility has been little used since its inception. This is because the FIMA facility is priced at 25 basis points above the IOER, which is higher than the repo rate from the private market for many central bank participants. Furthermore, the FIMA repo facility requires U.S. Treasury securities as collateral, so it is not as effective in addressing the cross-currency funding strain as the central bank swap line.

\section{CIP Deviations for Government Bond Yields}

To this point, we have primarily discussed CIP deviations for benchmark risk-free rate proxies facing large banks. In this section, we explore what can be learned from examining CIP deviations between government bond yields.

\subsection{Definition and Overview}

While CIP deviations between risk-free rates represent an arbitrage opportunity for global banks for the reasons discussed in the previous sections, CIP deviations may exist between 
government bond yields for several other reasons. There are three primary reasons that government bond yields might differ from risk-free rate proxies.

First, the yields could be lower than the risk-free rate because there are additional benefits to holding government bonds, such as greater liquidity and better collateral value. The yield differential that investors are willing to forgo while holding the government bond, relative to the risk-free rate, is referred to as the "convenience yield" of the government bond. Second, the government bond yield could be higher than the risk-free rate due to sovereign default risk. Third, the government bond yield could be different from the risk-free rate facing global investors due capital controls imposed by countries and the market segmentation between the domestic bond market and international capital market. CIP can then fail between government bond because of cross-country differences in convenience yields, sovereign default risk, and varying degrees of international capital market integration.

We begin by defining the CIP deviation between government bond yields as the difference between the synthetic dollar interest rate created by swapping foreign government bonds into U.S. dollars and the yield on the U.S. Treasury bonds:

$$
\Phi_{t, t+n}^{i / \$} \equiv-x_{t, t+n}^{i / \$, \text { Govt }}=\underbrace{y_{t, t+n}^{i, \text { Govt }}-\rho_{t, t+n}^{i / \$}}_{\text {Foreign Synthetic Dollar Yield }}-\underbrace{y_{t, t+n}^{\$, G o v t}}_{\text {U.S. Treasury Yield }},
$$

where $y_{t, t+n}^{i, G o v t}$ is the yield on country $i$ 's local currency government bond, $\rho_{t, t+n}^{i / \$}$ is the annualized forward premium of selling foreign currency $i$ in exchange for the U.S. dollar, and $y_{t, t+n}^{\$, G o v t}$ is the yield on the U.S. Treasury bond. We note that comparing equation 2 to equation 1 , we now define the government bond CIP deviation as the "negative" cross-currency basis for government bond yields. The reason for deliberately flipping the sign of the cross-currency basis is that it is more convenient to connect government CIP deviations defined in equation 2 to the concept of the "convenience yield" and "credit spread."

As an overview, Figure 12 plots the mean five-year CIP deviations relative to U.S. Treasury yields, $\Phi_{t, t+5}^{i / \$}$, for three groups of countries, "Developed Countries," "China, India, 
Indonesia, Philippines and Russia" and "Other Emerging Markets." ${ }^{21}$ For developed markets (in red), the mean government bond CIP deviation vis-à-vis the U.S. Treasury is positive before the GFC, increases during the GFC and then diminishes post-GFC. For the "Other Emerging Markets" group, the mean deviation is positive throughout the sample. For China, India, Indonesia, and Russia, we see that the mean deviation is generally positive outside the GFC period, but is very negative during the GFC.

In the rest of this section, we explain variations in the government bond CIP deviations across these groups of countries and how they have developed over time. We focus our discussion on the impact of government bond convenience yields for developed markets in Section 6.2, and the impact of sovereign default risk and capital controls for emerging markets in Section 6.3.

\subsection{Government Bond CIP Deviations between Developed Mar- kets and the US}

If investors value the liquidity and safety of government bonds, they may be willing to accept a lower yield to own them instead of other assets that promise the same cash flows. The extent to which they value these non-pecuniary benefits that reduce borrowing costs is often referred to as the "convenience yield." There is a large and growing literature on convenience yields within assets of the same currency (Krishnamurthy and Vissing-Jorgensen (2012), Greenwood, Hanson and Stein (2015), and Nagel (2016)). In this closed economy literature, the convenience yield on U.S. Treasuries or other safe assets would be defined as the agency-Treasury Spread (Krishnamurthy and Vissing-Jorgensen (2012), Longstaff (2004), and Schwarz (2019)), or the T-bill General Collateral (GC) repo rate (Nagel (2016)). ${ }^{22}$ However, when comparing across currencies, a straightforward comparison is more difficult.

\footnotetext{
${ }^{21}$ The group of "developed countries" include Australia, Canada, Switzerland, Denmark, Germany, the United Kingdom, Japan, Norway, New Zealand, and Sweden, and the group of "Other Emerging Markets" include Brazil, Chile, Colombia, Hungary, Israel, South Korea, Mexico, Malaysia, Peru, Poland, Thailand, Turkey, and South Africa.

${ }^{22}$ Mota (2020) examines the convenience yield on non-financial corporate bonds.
} 
In the absence of default risk and capital market frictions, CIP deviations between government bond yields offer a clean measure of the convenience yield differential on government bonds across countries (Du, Im and Schreger (2018b), Jiang, Krishnamurthy and Lustig (2018) and Engel and Wu (2018)). Because the cash flows on the two instruments are the same after being swapped into the same currency, any remaining yield difference represents non-pecuniary benefits from owning one asset instead of the other. These benefits include, for example, better liquidity, higher collateral value, or closer alignments with investment mandates.

The key assumptions that there is no sovereign default risk, nor any financial market frictions, are relatively good approximations for the group of developed countries pre-GFC. The ten developed countries in our sample have independent monetary policies (with Germany being the only exception), and the outright default risk on their local currency government bonds is thought to be quite low. Furthermore, as we have discussed, the CIP condition for benchmark interbank rates held remarkably well between these developed market currencies and the U.S. dollar. In addition, all sample developed countries have free capital mobility.

However, while the assumption of low default risk and free capital mobility continued to hold post-GFC, the assumption of no financial market friction is clearly violated based on our previous discussions of the CIP failure for benchmark bank rates. Therefore, we have to interpret government bond CIP deviations jointly with the CIP failure for benchmark bank rates. After all, the swap rates that we use to construct government CIP deviations are offered by banks, and therefore are subject to all the frictions in financial intermediation.

Figure 13 plots the mean government bond CIP deviations between developed countries (the G10) and the U.S. from January 2000 to August 2020. We find that the mean CIP deviations between the synthetic dollar yield on swapped foreign government bonds and the U.S. Treasury yield are positive across all maturities pre-GFC, suggesting a positive convenience yield on U.S. Treasury bonds. In particular, this convenience yield means that global investors were willing to forgo an average 20-30 basis points in yield to hold U.S. 
Treasury bonds as opposed to other alternative safe-haven government bonds pre-GFC. Du, Im and Schreger (2018b) refer to this convenience yield as the "specialness" of the U.S. Treasury bonds relative to other safe-haven alternatives. The U.S. Treasury specialness increased during the GFC across tenors, with the increase in the short tenors being the most pronounced. Interestingly, post-GFC, the U.S. Treasury specialness remains robust for the three-month and one-year maturity, but largely diminishes and even becomes negative at the five-year and ten-year maturity.

As discussed above, the interpretation of the government CIP deviations post-GFC should be put in the context of CIP deviations due to financial market frictions. Figure 14 overlays the government bond CIP deviations with the CIP deviations for the Libor and interest rate swap rates indexed to Libor at the three-month and ten-year maturities. The significant contrast between the short and long-term maturity, post-GFC, is that the short-maturity government bond CIP deviations track Libor CIP deviations very closely, whereas the longterm government bond CIP deviations diverge significantly from Libor CIP deviations. We can refer to the Libor CIP deviations as the specialness of dollar funding, which has emerged since the GFC as a result of limited financial intermediary capacity and strong demand for dollar funding and hedging that we described in Sections 4 and 5. Figure 14 then demonstrates that the specialness of U.S. Treasury securities is closely related to the specialness of dollar funding at short maturities post-GFC. However, long-term U.S. Treasury bonds have lost their specialness, despite the fact that long-term dollar funding remains quite special. In other words, the loss of the convenience yield in long-term Treasury bonds cannot be explained by the emergence of CIP deviations due to financial market frictions.

The stark contrast between the convenience yields on short-term and long-term U.S. Treasuries was on stark display during the peak of the pandemic-induced financial turmoil in March 2020. The yield on the long-term U.S. Treasury bond increased significantly on the most stressful days when the U.S. equity market hit limit downs, while the short-term U.S. T-bill yield dipped into negative territory. 
The declining convenience of long-term Treasury bonds relative to other safe havens raises questions about the position of U.S. Treasury bonds as the global safe asset. The literature has discussed some potential explanations for the diminishing specialness. First, the United States has a faster-growing U.S. debt-to-GDP ratio relative to the other safe havens on average post-GFC (Du, Im and Schreger (2018b)). A relative increase in the supply of U.S. Treasury bonds makes them less special (Krishnamurthy and Vissing-Jorgensen (2012)). ${ }^{23}$ Second, the loss of specicalness of U.S. Treasury bonds could again be linked to increased costs of intermediation due to tighter non-risk-weighted leverage constraints postGFC (Duffie (2020) and He, Nagel and Song (2020)). Banks and dealers face higher balance sheet costs of holding Treasury bonds and in providing funding to clients to finance their Treasury holdings in the repo market. These additional costs decrease Treasury specialness.

More generally, there remains much work to be done to better understand the sources and the time-variations in the "convenience yield" of the U.S. Treasury bonds in the presence of financial market frictions post-GFC, whether it is driven by additional liquidity, safety, collateral value of the U.S. Treasury bonds, relative debt supply across countries, dealers' different balance sheet capacities in intermediating Treasury securities, and/or the premium associated with the U.S. dollar being the international reserve currency. ${ }^{24}$ In addition, the connection between the relative specialness of Treasuries and the specialness of dollar in the international monetary system is an important open question.

\footnotetext{
${ }^{23}$ However, while a reduction in the the convenience yield today implies U.S. Treasury rates are reduced less than previously at the margin, the U.S. still would have seen its yield reduced significantly on all of its inframarginal debt issuance.

${ }^{24}$ For an examination of safety, see Caballero et al. (2017), Caballero and Farhi (2018) and Gorton (2017) among others. For models on international reserve currency, see Maggiori (2017), Farhi and Maggiori (2018), He, Krishnamurthy and Milbradt (2019), and Gopinath and Stein (2018). Jiang, Krishnamurthy and Lustig (2018) present an extension to their baseline model where the relative convenience yield on Treasuries is a function of the CIP deviation between risk-free rates.
} 


\subsection{Government Bond CIP Deviations Between Emerging Mar- kets and the U.S.}

As we have seen in Figure 12, emerging market bonds have significantly larger CIP deviations from the U.S. Treasury bonds compared to developed markets. Du and Schreger (2016) refer to the government bond CIP deviations for emerging market sovereigns as the "local currency credit spread." This is because the underlying risk of the emerging market sovereigns defaulting on their local currency debt could be an important reason why CIP fails in this case. In Figure 15, we plot the mean CIP deviations for emerging market bonds against their sovereign CDS spreads, denominated in dollars. As we can see, the two measures have strong co-movement, particularly from 2005-2013. The average plot hides a large degree of crosscountry heterogeneity, as the within-country correlation between the local currency credit spread (or government CIP deviations) and the sovereign CDS spread ranges from 95\% for Poland to $1 \%$ for Brazil. As CDS spreads give a risk-neutral expectation of the expected loss of a default on the sovereign debt that is issued by the same government, the co-movement between government bond CIP deviations and sovereign credit spreads provides empirical support that sovereign default risk is driving the government bond CIP deviations between emerging markets and the U.S. ${ }^{25}$

However, sovereign default risk is not the only source of variation for emerging market government bond CIP deviations. In Figure 12, we see that the average CIP deviations for China, India, Indonesia, Philippines, and Russia display a markedly different pattern than the other emerging market countries, particularly so during the GFC. These countries have strong capital controls that restrict foreign participation (foreign capital inflows) in

\footnotetext{
${ }^{25}$ This, of course, raises the question of why governments would be charged a credit spread for borrowing in their own currencies when they could always just inflate the debt away. Du and Schreger (2017) and $\mathrm{Wu}$ (2020) emphasize the importance of foreign currency corporate debt. Aguiar et al. (2013), and Galli (2020) examine the effect of varying inflation costs. Reinhart and Rogoff (2011) document the long history of domestic default, including debt in local currency. Jeanneret and Souissi (2016) examine the relative prevalence of default by domestic currency. Hofmann et al. (2020) demonstrates that reductions in local currency credits spreads in emerging markets are associated with appreciations of the local currency against the U.S. dollar. The authors argue the changes in spreads are driven by shifts in risk premia. Kalemli-Ozcan and Varela (2019) show that political risk affects interest rates in emerging markets.
} 
the local currency government bond markets, and/or limits on the international investments of local institutional investors. These capital controls create segmentation in clientele and market liquidity between the domestic government bond and the offshore, non-deliverable, cross-currency swap markets. In particular, during times of global financial distress, the rise in the local currency bond yields in emerging markets is more muted due to local clientele effects, while the forward premium and CDS spreads spike in tandem with the heightened risk aversion of global investors, creating a significant negative local currency "credit" spread. The co-movement, or the lack thereof, between the onshore local currency bond yields and the offshore non-deliverable cross-currency swap rates potentially offers researchers a de facto measure of market integration and capital controls.

\section{Exchange Rates and CIP Deviations}

With CIP deviations representing a significant departure from a fundamental relationship in currency markets, one may hope this change helps shed light on the core exchange rate puzzles in international finance. ${ }^{26}$ Presently, there are two lines of thinking about the role of CIP deviations in exchange rate determination.

First, focusing on CIP deviations between risk-free rates, Avdjiev et al. (2019) argue that there should be a connection between movements in the broad U.S. dollar and Libor CIP deviations, because the dollar acts as a barometer of risk-taking capacity in global capital markets and the CIP deviations capture the shadow costs on the balance sheet constraints of the financial intermediary. This line of argument is also consistent with the ideas of Gabaix and Maggiori (2015) on the central role of constrained intermediaries for the determination of exchange rates. ${ }^{27}$ Lilley et al. (Forthcoming) document a structural break in the relationship between exchange rates, capital flows, and risk measures around the global financial crisis

\footnotetext{
${ }^{26}$ There is an enormous literature on the challenges of explaining movements in nominal exchange rates. See, for instance, Meese and Rogoff (1983), Frankel and Rose (1995), and Engel and West (2005))

${ }^{27}$ The idea of the dollar as a global risk factor builds on the work of Bruno and Shin (2015a) and Bruno and Shin (2015b). Adrian, Etula and Shin (2010) connect the movement of the dollar to movement in USD bank lending.
} 
and that if CIP deviations were a measure of the risk-bearing capacity of the financial system, it would be natural for CIP deviations to co-vary with the dollar along with other risk measures. This first line of thinking treats CIP deviations essentially as a signal of financial market constraints, which in turn drive exchange rate movements, rather than as a determinant of exchange rates themselves.

The second line of research focuses on the idea that if bonds earn a liquidity premium, or a convenience yield as near-money assets, then they have the potential to explain a number of exchange rate puzzles. For instance, Engel (2016) demonstrates that the UIP puzzle changes signs at various horizons, with high interest rate countries experiencing high returns in the short-run, but also forecasting lower returns at longer horizons. Engel (2016) suggests that the liquidity premia on bonds, due to their preferred safety and collateral value, can help rationalize this puzzle, with Valchev (2020) proposing a related explanation for this empirical pattern by working through the endogenous bond convenience yields resulting from monetary and fiscal policy interaction. Conceptually, the failure of UIP means that the path of interest rates will be insufficient to explain the value of a currency, but perhaps this well-known failure is explained by the existence of a non-pecuniary benefit that investors realize by holding different assets. Jiang, Krishnamurthy and Lustig (2018) and Engel and Wu (2018) study the relationship between the convenience yields and exchange rates empirically. They both use the deviation from CIP between the U.S. government and FX-hedged foreign government bond yields as their measure of convenience. This line of thinking treats changes in CIP deviations, capturing changes in relative convenience yields, as a driving source of exchange rates rather than just a valuable signal. Kekre and Lenel (2021) build a two-country New Keynesian model with heterogeneity in risk-bearing capacity within and between countries to explain the dollar carry trade, as well as the outsize importance of U.S. monetary policy shocks and the composition of international portfolios. "Safety shocks" are the driving force of the model and these shocks are calibrated to match the properties of CIP deviations between U.S. Treasuries and foreign government bonds. 
Building on Campbell and Clarida (1987), Clarida and Gali (1994), and Froot and Ramadorai (2005), Jiang, Krishnamurthy and Lustig (2018) derive a version of the present value decomposition for exchange rates, introducing a new term for CIP deviations. The classical present value formula for the spot exchange rate without bond CIP deviations depends on the future path of the interest rate differential, risk premia, and the long-term level of the exchange rate. In addition to these terms, Jiang, Krishnamurthy and Lustig (2018) introduce a new term for the full path of relative convenience yields as measured by the CIP deviation between government bond yields. As a result, some of the fluctuations that the previous literature would have attributed to movements in currency risk premia should be better thought of as coming from CIP deviations. ${ }^{28}$

We now directly examine how CIP deviations co-vary with exchange rates empirically. We first examine how the average cross-currency basis co-varies with the broad dollar exchange rate, an equal-weighted index of bilateral dollar exchange rates. In Table 4, we run univariate regressions of the form

$$
\Delta e_{t}^{\$}=\alpha+\beta \Delta \bar{x}_{t}+\epsilon_{t}
$$

where $\Delta e_{t}^{\$}$ is the quarterly log change in the broad dollar exchange rate and $\Delta \bar{x}_{t}$ is the quarterly change in the average cross-currency basis of the G10 currencies vis-à-vis the U.S. dollar. We consider both IBOR-based and government bond-based cross-currency basis and run quarterly regressions on the post-GFC sample from 2008Q1 to 2020Q2. ${ }^{29}$ We see that for both IBOR-based and government bond-based measures, quarterly changes in the crosscurrency basis have little explanatory power for quarterly changes in the spot exchange rate. However, changes in longer-dated cross-currency basis have strong explanatory power for the spot exchange rate, with a univariate regression on the 5-year Libor basis (the benchmark used in Avdjiev et al. (2019)) having an $R^{2}$ of $30 \%$ and the 1-year government bond basis (the benchmark used in Jiang, Krishnamurthy and Lustig (2018) and Engel and Wu (2018))

\footnotetext{
${ }^{28}$ Engel and $\mathrm{Wu}(2018)$ derive a similar expression beginning from an open-economy New Keynesian model.

${ }^{29} \mathrm{Jiang}$ et al. (2018) and Engel and Wu (2018) have earlier starting dates because they focus on government bond CIP deviations and this exercise compares bond and Libor CIP deviations.
} 
having an $R^{2}$ of $32 \%$.

We now study how the cross-currency basis co-moves with the bilateral exchange rate against the U.S. dollar. We run a series of univariate regressions of the following forms:

$$
\begin{aligned}
& \Delta e_{t}^{i / \$}=\alpha_{i}+\beta_{i} \Delta \bar{x}_{t}+\epsilon_{i, t}, \\
& \Delta e_{t}^{i / \$}=\alpha_{i}+\beta_{i} \Delta x_{i, t}+\epsilon_{i, t}
\end{aligned}
$$

where $\Delta e_{t}^{i / \$}$ is the quarterly log change in the currency's bilateral exchange rate against the U.S. dollar. Here, in addition to reporting the regression coefficients and $R^{2}$ for changes in the bilateral exchange rate on changes in the average cross-currency basis, $\Delta \bar{x}_{t}$, we also report regression results for running the changes in the bilateral exchange rates on the bilateral cross-currency basis vis-à-vis the dollar, $\Delta x_{i, t}$. We run regressions using both the one-year and the five-year cross-currency basis. Table 5 presents regression results. We find that the bilateral exchange rate also generally loads negatively on the cross-currency basis, consistent with the evidence in Engel and Wu (2018). The explanatory power of the mean cross-currency (both for Libor and government bonds) is generally higher than that of the bilateral cross-currency basis against the USD. ${ }^{30}$ The notable exception is that the dollar-yen exchange rate has very little correlation with any cross-currency basis measure.

\section{Takeaways and Open Research Questions}

Given that a persistent failure of CIP has emerged for fewer than 15 years, the literature surveyed in this paper is still in a relative early stage. In this section, we highlight several important future research directions for us to better understand the landscape of global dollar funding markets and its macroeconomic implications.

\footnotetext{
${ }^{30}$ Krishnamurthy and Lustig (2019) examine the bilateral explanatory power of CIP deviations between government bonds.
} 
Re-thinking post-GFC banking regulations A central theme of this chapter is that balance sheet constraints facing large global banks as a result of post-GFC regulatory reforms have reduced the willingness and capacity of large banks to intermediate in the dollar funding markets, resulting in persistent CIP failure. It is natural to ask the question whether these post-GFC banking regulations are optimal. While there is an inherent tradeoff between efficiency of financial intermediation and overall financial market stability, one view is that a binding non-risk-weighted capital constraint places us in the interior of the efficiencystability frontier (Duffie (2017)). Meanwhile, it is clear that excessive leverage is one of the main contributors to past financial crises, and ex-ante assessments of risk weights of assets can be misguided. These reasons argue in favor of maintaining a minimum non-risk-weighted capital standard.

A set of policy design questions follow naturally. How should policymakers calibrate the risk-weighted and non-risk-weighted capital regulations? Should central bank reserves and/or Treasury securities be exempted from the leverage ratio calculation? Should the public disclosure of the leverage ratio move to a daily-averaging regime in all major jurisdictions to avoid reporting-period window-dressing?

In addition, the repo market turmoil in September 2019 shed light on additional bank balance sheet frictions beyond Basel III regulatory metrics, most prominently the intraday liquidity constraint. More research is needed to examine other dimensions of banking regulations that have implications for dollar liquidity provision beyond capital requirements.

The role of non-banks While the bulk of the papers we surveyed emphasized the role of large global banks, non-banks play an increasingly important role in the overall landscape of global dollar funding markets. Given that the growth of the banking sector remained subdued post-GFC, non-banks account for an increasing share of the demand for dollar funding and hedging services. Furthermore, dollar-rich real-money investors can also become more active dollar lenders to mitigate global dollar liquidity shortage. 
There are very few systematic studies in this area, which opens up a great opportunity for fruitful future research. A few specific examples are given below, which are by no means exhaustive. For institutional investors, it would be useful to have a better understanding of the relationship between CIP deviations and their investment demand and currency hedging decisions. For real-money dollar investors, such as investment managers at central bank FX reserves, sovereign wealth funds, U.S. pensions and insurance firms, we need further research to pinpoint specific barriers for them to become large dollar lenders in the FX swap market. For corporate issuers, more research can shed further light into international capital market frictions that lead to market segmentation by currency in cash markets and how these frictions interact with corporate funding and investment decisions across currencies and geography.

Macroeconomic implications of CIP deviations The offshore dollar funding markets in the FX swap markets are an integral part of the global dollar funding markets, and CIP deviations are a gauge of the offshore dollar funding conditions. Fragility and vulnerabilities in the offshore dollar funding markets pose stability risk to the overall global financial system. Given the predominant role of the U.S. dollar in global financial markets, it is impossible for the Federal Reserve to focus exclusively on domestic financial conditions. The role of the Fed as a quasi-global lender of last resort and the availability of the central bank toolkit are important areas for future research.

It is also important to understand the welfare implications of CIP deviations. It is an open question whether CIP deviations represent deadweight losses due to distortions in dollar investment and hedging decisions or are evidence of tighter and more effective regulation. ${ }^{31}$ To quantify these welfare costs, one not only needs a fully-fledged model, but also more micro-evidence on who is paying a higher cost and by how much. The bulk of the empirical analysis on CIP deviations so far use benchmark interest rates, which is inadequate

\footnotetext{
${ }^{31}$ Hébert (2020) theoretically examines the welfare consequences of the existence of such arbitrage opportunities.
} 
in addressing the large heterogeneity in the access to dollar funding across different types of market participants.

From a theory perspective, the existence of CIP deviations provides a laboratory for researchers to test intermediary asset pricing theory (He and Krishnamurthy (2013), He and Krishnamurthy (2018)). The CIP deviations are likely the tip of the iceberg, as the balance sheet constraints that underline the CIP deviations should be present in all asset classes. ${ }^{32}$

Finally, we are only beginning to scratch the surface of the international macroeconomic consequences of the breakdown of CIP. Compared to the UIP failure, ${ }^{33}$ the failure of CIP also offers a more stringent testing ground for international macro-finance models. While there is now an extensive theoretical literature that rationalizes UIP deviations by introducing risk premia that make currencies imperfect substitutes, only models with binding financial constraints can generate CIP deviations. Along these lines, Gabaix and Maggiori (2015) introduced a theoretical framework for the determination of exchange rates under segmented markets. This literature is rapidly growing (Jiang, Krishnamurthy and Lustig (2020), Greenwood, Hanson, Stein and Sunderam (2020), Gourinchas, Ray and Vayanos (2019), Bianchi, Bigio and Engel (2020), Itskhoki and Mukhin (2017), Itskhoki and Mukhin (2019)) and Kekre and Lenel (2021), and is reviewed in the Handbook Chapter by Maggiori (2021).

\section{Conclusion}

Covered interest rate parity has long been a foundational relationship in international finance and macroeconomics. Its breakdown represents a significant change in global financial markets. The cross-currency basis has emerged from an esoteric corner of the FX derivative market to become an important barometer of the health of global capital markets. The breakdown of CIP puts financial frictions and intermediary constraints at the heart of inter-

\footnotetext{
${ }^{32} \mathrm{Du}$, Hébert and Huber (2019) further argue the co-variance with the future fluctuation in the balance sheet constraint is a priced risk factor.

${ }^{33}$ See Engel (2014) and Hassan and Zhang (2020) for recent surveys.
} 
national finance and macroeconomics.

\section{References}

Abbassi, Puriya and Falk Bräuning, "Demand Effects in the FX Forward Market: Micro Evidence from Banks' Dollar Hedging," Review of Financial Studies, forthcoming, 2020.

Adrian, Tobias, Erkko Etula, and Hyun Song Shin, "Risk appetite and exchange rates," FRB of New York Staff Report, 2010, (361).

Afonso, Gara, Fabiola Ravazzolo, and Alessandro Zori, "From Policy Rates to Market Rates-Untangling the US Dollar Funding Market," Technical Report, Federal Reserve Bank of New York 2019.

Aguiar, Mark, Manuel Amador, Emmanuel Farhi, and Gita Gopinath, "Crisis and commitment: Inflation credibility and the vulnerability to sovereign debt crises," Technical Report, National Bureau of Economic Research 2013.

Akram, Q Farooq, Dagfinn Rime, and Lucio Sarno, "Arbitrage in the foreign exchange market: Turning on the microscope," Journal of International Economics, 2008, 76 (2), $237-253$.

Aldasoro, Iñaki and Torsten Ehlers, "The geography of dollar funding of non-US banks," BIS Quarterly Review December, 2018.

_, Egemen Eren, and Wenqian Huang, "Dollar funding of non-US Banks through Covid-19," 2021.

Alfaro, Laura, Mauricio Calani, and Liliana Varela, "Currency Hedging in Emerging Markets," Working Paper, 2021.

Amador, Manuel, Javier Bianchi, Luigi Bocola, and Fabrizio Perri, "Exchange rate policies at the zero lower bound," The Review of Economic Studies, 2020, 87 (4), 1605-1645.

Andersen, Leif, Darrell Duffie, and Yang Song, "Funding value adjustments," The Journal of Finance, 2019, 74 (1), 145-192.

Anderson, Alyssa, Wenxin Du, and Bernd Schlusche, "Arbitrage Capital of Global Banks," University of Chicago Working Paper, 2019.

Augustin, Patrick, Mikhail Chernov, Lukas Schmid, and Dongho Song, "The term structure of CIP violations," 2021.

Avdjiev, Stefan, Egemen Eren, Patrick McGuire et al., "Dollar funding costs during the Covid-19 crisis through the lens of the FX swap market," Technical Report, Bank for International Settlements 2020.

_, Wenxin Du, Catherine Koch, and Hyun Song Shin, "The dollar, bank leverage, and deviations from covered interest parity," American Economic Review: Insights, 2019, 1 (2), 193-208.

Bahaj, Saleem and Ricardo Reis, "Central bank swap lines," 2018.

_ and _, "Central bank swap lines during the Covid-19 pandemic," Covid Economics, 2020, 2, 1-12. 
Bai, Jennie and Pierre Collin-Dufresne, "The CDS-bond basis," Financial Management, 2019, 48 (2), 417-439.

Banegas, Ayelen and Manjola Tase, "Reserve balances, the federal funds market and arbitrage in the new regulatory framework," Journal of Banking 83 Finance, 2020, 118, 105893.

Bank for International Settlements, "US dollar funding: an international perspective," CGFS Paper No. 65, 2020.

Barajas, Mr Adolfo, Andrea Deghi, Claudio Raddatz, MissDulani Seneviratne, Peichu Xie, and Yizhi Xu, Global Banks' Dollar Funding: A Source of Financial Vulnerability, International Monetary Fund, 2020.

Bekaert, Geert, Marie Hoerova, and Marco Lo Duca, "Risk, uncertainty and monetary policy," Journal of Monetary Economics, 2013, 60 (7), 771-788.

Bianchi, Javier, Saki Bigio, and Charles Engel, "Scrambling for Dollars: International Liquidity, Banks and Exchange Rates," 2020.

Borio, Claudio EV, Robert N McCauley, Patrick McGuire, and Vladyslav Sushko, "Covered interest parity lost: understanding the cross-currency basis," BIS Quarterly Review September, 2016.

Boyarchenko, Nina, Thomas M Eisenbach, Pooja Gupta, Or Shachar, and Peter Van Tassel, "Bank-intermediated arbitrage," 2020.

Bruno, Valentina and Hyun Song Shin, "Capital flows and the risk-taking channel of monetary policy," Journal of Monetary Economics, 2015, 71, 119-132.

- and _ "Cross-border banking and global liquidity," The Review of Economic Studies, 2015, $82(2), 535-564$.

_ and _, "Global dollar credit and carry trades: a firm-level analysis," The Review of Financial Studies, 2017, 30 (3), 703-749.

_ and _, "Currency depreciation and emerging market corporate distress," Management Science, 2020, 66 (5), 1935-1961.

Burger, John D, Francis E Warnock, and Veronica Cacdac Warnock, "Currency matters: Analyzing international bond portfolios," Journal of International Economics, 2018, 114, 376-388.

Caballero, Ricardo and Emmanuel Farhi, "The safety trap," The Review of Economic Studies, 2018, 85 (1), 223-274.

Caballero, Ricardo J, Emmanuel Farhi, and Pierre-Olivier Gourinchas, "The safe assets shortage conundrum," Journal of Economic Perspectives, 2017, 31 (3), 29-46.

Campbell, John Y and Richard H Clarida, "The dollar and real interest rates," in "Carnegie-Rochester Conference Series on Public Policy," Vol. 27 Elsevier 1987, pp. 103139.

Cenedese, Gino, Pasquale Della Corte, and Tianyu Wang, "Currency mispricing and dealer balance sheets," Journal of Finance, 2020.

Cerutti, Eugenio M, Maurice Obstfeld, and Haonan Zhou, "Covered Interest Parity Deviations: Macrofinancial Determinants," Technical Report, National Bureau of Economic Research 2019.

Cetorelli, Nicola, Linda S Goldberg, Fabiola Ravazzolo et al., "Have the Fed Swap Lines Reduced Dollar Funding Strains during the COVID-19 Outbreak?," Technical Report, Federal Reserve Bank of New York 2020. 
Chernenko, Sergey and Adi Sunderam, "Frictions in shadow banking: Evidence from the lending behavior of money market mutual funds," The Review of Financial Studies, 2014, 27 (6), 1717-1750.

Chien, YiLi, Hanno Lustig, Kanda Naknoi et al., Why are Exchange Rates So Smooth?: A Segmented Asset Markets Explanation, Federal Reserve Bank of St. Louis, Research Division, 2015.

Clarida, Richard and Jordi Gali, "Sources of real exchange-rate fluctuations: How important are nominal shocks?," in "Carnegie-Rochester conference series on public policy," Vol. 41 Elsevier 1994, pp. 1-56.

Copeland, Adam, Darrell Duffie, and Yilin (David) Yang, "Reserves were not so ample after all - evidence from the U.S. Treasury repo market," Stanford University Working Paper, 2020.

_, Isaac Davis, Eric LeSueur, and Antoine Martin, "Mapping and sizing the US repo market," Technical Report, Federal Reserve Bank of New York 2012.

${ }_{-},{ }_{-}, \ldots$, and _ , "Lifting the veil on the us bilateral repo market," Technical Report, Federal Reserve Bank of New York 2014.

Correa, Ricardo, Wenxin Du, and Gordon Liao, "U.S. banks and global liquidity," NBER Working Paper, 2020, (w27491).

Debelle, G, "How I learned to stop worrying and love the basis," in "Dinner address at the BIS Symposium: CIP-RIP" 2017.

Dedola, Luca, Georgios Georgiadis, Johannes Gräb, and Arnaud Mehl, "Does a big bazooka matter? Quantitative easing policies and exchange rates," Journal of Monetary Economics, 2021, 117, 489-506.

Dou, Winston Wei and Adrien Verdelhan, "The volatility of international capital flows and foreign assets," Unpublished Working Paper, MIT, 2015.

Du, Wenxin, Alexander Tepper, and Adrien Verdelhan, "Deviations from covered interest rate parity," The Journal of Finance, 2018, 73 (3), 915-957.

- and Jesse Schreger, "Local currency sovereign risk," The Journal of Finance, 2016, 71 (3), 1027-1070.

_ and _ , "Sovereign risk, currency risk, and corporate balance sheets," Working Paper, 2017, (17-024).

_, Benjamin M Hébert, and Amy Wang Huber, "Are Intermediary Constraints Priced?," Technical Report, National Bureau of Economic Research 2019.

_ , Joanne Im, and Jesse Schreger, "The US treasury premium," Journal of International Economics, 2018, 112, 167-181.

Duffie, Darrell, Post-crisis bank regulations and financial market liquidity, Banca d'Italia, 2017.

_ , "Still the World's Safe Haven?," Redesigning the US Treasury Market After the COVID19 Crisis. Hutchins Center Working Paper, 2020, (62).

Engel, Charles, "Exchange rates and interest parity," Handbook of international economics, 2014, 4, 453-522.

_ , "Exchange rates, interest rates, and the risk premium," American Economic Review, 2016, 106 (2), 436-74.

- and Kenneth D West, "Exchange rates and fundamentals," Journal of political Economy, 2005, 113 (3), 485-517. 
- and Steve Pak Yeung Wu, "Liquidity and exchange rates: An empirical investigation," Technical Report, National Bureau of Economic Research 2018.

Eren, Egemen, Andreas Schrimpf, and Vladyslav Sushko, "US dollar funding markets during the Covid-19 crisis - the international dimension," BIS Bulletin, 2020, (15).

Farhi, Emmanuel and Matteo Maggiori, "A model of the international monetary system," The Quarterly Journal of Economics, 2018, 133 (1), 295-355.

Fleckenstein, Matthias and Francis A Longstaff, "Renting Balance Sheet Space: Intermediary Balance Sheet Rental Costs and the Valuation of Derivatives," The Review of Financial Studies, 2020, 33 (11), 5051-5091.

Frankel, Jeffrey A and Andrew K Rose, "Empirical research on nominal exchange rates," Handbook of international economics, 1995, 3, 1689-1729.

Frenkel, Jacob A and Richard M Levich, "Covered interest arbitrage: Unexploited profits?," Journal of Political Economy, 1975, 83 (2), 325-338.

- and _ , "Transaction costs and interest arbitrage: Tranquil versus turbulent periods," Journal of Political Economy, 1977, 85 (6), 1209-1226.

Froot, Kenneth A and Tarun Ramadorai, "Currency returns, intrinsic value, and institutional-investor flows," The Journal of Finance, 2005, 60 (3), 1535-1566.

Gabaix, Xavier and Matteo Maggiori, "International liquidity and exchange rate dynamics," The Quarterly Journal of Economics, 2015, 130 (3), 1369-1420.

Galli, Carlo, "Inflation, Default Risk and Nominal Debt," 2020.

Garleanu, Nicolae and Lasse Heje Pedersen, "Margin-based asset pricing and deviations from the law of one price," The Review of Financial Studies, 2011, 24 (6), 1980-2022.

Goldberg, Linda S, Craig Kennedy, and Jason Miu, "Central bank dollar swap lines and overseas dollar funding costs," Technical Report, National Bureau of Economic Research 2010.

Gopinath, Gita and Jeremy C Stein, "Banking, Trade, and the making of a Dominant Currency," Technical Report, National Bureau of Economic Research 2018.

Gorton, Gary, "The history and economics of safe assets," Annual Review of Economics, $2017,9,547-586$.

Goto, Yujiro and Yusuke Miyairi, "Lifers' FX Hedge Ratio Inched Down," Technical Report, Nomura JPY Weekly 2019.

Gourinchas, Pierre-Olivier, Walker Ray, and Dimitri Vayanos, "A preferred-habitat model of term premia and currency risk," Technical Report, mimeo 2019.

Greenwood, Robin M, Samuel Gregory Hanson, Jeremy C Stein, and Aditya Sunderam, "A Quantity-Driven Theory of Term Premia and Exchange Rates," NBER Working Paper, 2020, (w27615).

Greenwood, Robin, Samuel G Hanson, and Jeremy C Stein, "A comparativeadvantage approach to government debt maturity," The Journal of Finance, 2015, 70 (4), 1683-1722.

Hassan, Tarek A and Rui C Mano, "Forward and spot exchange rates in a multi-currency world," The Quarterly Journal of Economics, 2019, 134 (1), 397-450.

Hassan, Tarek Alexander and Tony Zhang, "The Economics of Currency Risk," NBER Working Paper, 2020, (w27847).

He, Zhiguo and Arvind Krishnamurthy, "Intermediary asset pricing," American Economic Review, 2013, 103 (2), 732-70. 
_ and _ , "Intermediary asset pricing and the financial crisis," Annual Review of Financial Economics, 2018, 10, 173-197.

_, _, and Konstantin Milbradt, "A model of safe asset determination," American Economic Review, 2019, 109 (4), 1230-62.

_, Bryan Kelly, and Asaf Manela, "Intermediary asset pricing: New evidence from many asset classes," Journal of Financial Economics, 2017, 126 (1), 1-35.

_, Stefan Nagel, and Zhaogang Song, "Treasury inconvenience yields during the covid19 crisis," NBER Working Paper, 2020, (w27416).

Hébert, Benjamin M, "Externalities as arbitrage," Technical Report, National Bureau of Economic Research 2020.

Hofmann, Boris, Ilhyock Shim, and Hyun Song Shin, "Bond risk premia and the exchange rate," Journal of Money, Credit and Banking, 2020, 52 (S2), 497-520.

Iida, Tomoyuki, Takeshi Kimura, and Nao Sudo, "Deviations from Covered Interest Rate Parity and the Dollar Funding of Global Banks," International Journal of Central Banking, 2018, 14 (4), 275-325.

IMF, "Banks' Dollar Funding: A Source of Financial Vulnerability," Global Financial Stability Report: Lower for Longer, 2019.

Itskhoki, Oleg and Dmitry Mukhin, "Exchange rate disconnect in general equilibrium," Technical Report, National Bureau of Economic Research 2017.

_ and _ , "Mussa puzzle redux," Available at SSRN 3423438, 2019.

Ivashina, Victoria, David S Scharfstein, and Jeremy C Stein, "Dollar funding and the lending behavior of global banks," The Quarterly Journal of Economics, 2015, 130 (3), 1241-1281.

Jeanneret, Alexandre and Slim Souissi, "Sovereign defaults by currency denomination," Journal of International Money and Finance, 2016, 60, 197-222.

Jermann, Urban, "Negative swap spreads and limited arbitrage," The Review of Financial Studies, 2020, 33 (1), 212-238.

Jiang, Zhengyang, Arvind Krishnamurthy, and Hanno Lustig, "Foreign safe asset demand and the dollar exchange rate," Technical Report, National Bureau of Economic Research 2018.

_ , , and _, "Dollar safety and the global financial cycle," Technical Report, National Bureau of Economic Research 2020.

Kalemli-Ozcan, S and Liliana Varela, "Exchange Rate and Interest Rate Disconnect: The Role of Capital Flows and Risk Premia," Technical Report, Discussion paper, mimeo 2019.

Kalemli-Özcan, Șebnem, "US monetary policy and international risk spillovers," Technical Report, National Bureau of Economic Research 2019.

Keerati, Ritt, "The Impact of Monetary Policy on the Specialness of US Treasuries," Available at SSRN 3682897, 2020.

Kekre, Rohan and Moritz Lenel, "The Flight to Safety and International Risk Sharing," University of Chicago and Prince University Working Paper, 2021.

Klingler, Sven and Suresh Sundaresan, "An explanation of negative swap spreads: Demand for duration from underfunded pension plans," The Journal of Finance, 2019, 74 (2), 675-710. 
Krishnamurthy, Arvind and Annette Vissing-Jorgensen, "The aggregate demand for treasury debt," Journal of Political Economy, 2012, 120 (2), 233-267.

_ and Hanno N Lustig, "Mind the gap in sovereign debt markets: The US Treasury basis and the dollar risk factor," in "2019 Jackson Hole Economic Symposium" 2019.

Levich, Richard, "CIP: Then and Now, A Brief Survey of Measuring and Exploiting Deviations from Covered Interest Parity," in "BIS Symposium: CIP - RIP?" 2017.

Liao, Gordon and Tony Zhang, "The Hedging Channel of Exchange Rate Determination," Available at SSRN 3612395, 2020.

Liao, Gordon Y, "Credit migration and covered interest rate parity," Journal of Financial Economics, 2020.

Lilley, Andrew, Matteo Maggiori, Brent Neiman, and Jesse Schreger, "Exchange rate reconnect," Review of Economics and Statistics, Forthcoming.

Longstaff, Francis A, "The flight-to-liquidity premium in US Treasury bond prices," Journal of Business, 2004, 7 ry (3), 511-526.

Lustig, Hanno and Adrien Verdelhan, "The cross section of foreign currency risk premia and consumption growth risk," American Economic Review, 2007, 97 (1), 89-117.

_ and _, "Does incomplete spanning in international financial markets help to explain exchange rates?," American Economic Review, 2019, 109 (6), 2208-44.

_, Nikolai Roussanov, and Adrien Verdelhan, "Common risk factors in currency markets," The Review of Financial Studies, 2011, 24 (11), 3731-3777.

Maggiori, Matteo, "Financial intermediation, international risk sharing, and reserve currencies," American Economic Review, 2017, 107 (10), 3038-71.

_ , "International Macroeconomics with Imperfect Financial Markets," Handbook of International Economics, 2021.

_ , Brent Neiman, and Jesse Schreger, "International currencies and capital allocation," Journal of Political Economy, 2020, 128 (6), 2019-2066.

McBrady, Matthew R and Michael J Schill, "Foreign currency-denominated borrowing in the absence of operating incentives," Journal of Financial Economics, 2007, 86 (1), 145177.

McCauley, Robert N and Catherine R Schenk, "Central bank swaps then and now: swaps and dollar liquidity in the 1960s," 2020.

McGuire, Patrick and Goetz Von Peter, "The US dollar shortage in global banking and the international policy response," 2009.

Meese, Richard A and Kenneth Rogoff, "Empirical exchange rate models of the seventies: Do they fit out of sample?," Journal of international economics, 1983, 14 (1-2), 3-24.

Miranda-Agrippino, Silvia and Hélene Rey, "US monetary policy and the global financial cycle," The Review of Economic Studies, 2020, 87 (6), 2754-2776.

Mota, Lira, "The Corporate Supply of (Quasi) Safe Assets," Available at SSRN, 2020.

Nagel, Stefan, "The liquidity premium of near-money assets," The Quarterly Journal of Economics, 2016, 131 (4), 1927-1971.

Obstfeld, Maurice, "International capital mobility in the 1990s," Technical Report, National Bureau of Economic Research 1993.

Pasquariello, Paolo, "Financial market dislocations," The Review of Financial Studies, 2014, 27 (6), 1868-1914. 
Popper, Helen, "Long-term covered interest parity: evidence from currency swaps," Journal of International Money and Finance, 1993, 12 (4), 439-448.

Reinhart, Carmen M and Kenneth S Rogoff, "The forgotten history of domestic debt," The Economic Journal, 2011, 121 (552), 319-350.

Rime, Dagfinn, Andreas Schrimpf, and Olav Syrstad, "Covered interest parity arbitrage," Available at SSRN 2879904, 2019.

Rogoff, Kenneth, "Can exchange rate predictability be achieved without monetary convergence?: Evidence from the EMS," European Economic Review, 1985, 28 (1-2), 93-115.

Salomao, Juliana and Liliana Varela, "Exchange rate exposure and firm dynamics," 2018.

Schwarz, Krista, "Mind the gap: Disentangling credit and liquidity in risk spreads," Review of Finance, 2019, 23 (3), 557-597.

Setser, Brad W. and S.T.W, "Shadow FX Intervention in Taiwan: Solving a USD 100+ Billion Enigma," Council on Foreign Relations Report, 2019.

Shleifer, Andrei and Robert W Vishny, "The limits of arbitrage," The Journal of finance, 1997, 52 (1), 35-55.

Song, Zhaogang and Haoxiang Zhu, "Mortgage dollar roll," The Review of Financial Studies, 2019, 32 (8), 2955-2996.

Valchev, Rosen, "Bond convenience yields and exchange rate dynamics," American Economic Journal: Macroeconomics, 2020, 12 (2), 124-66.

Viswanath-Natraj, Ganesh, "Unconventional Monetary Policy and Covered Interest Rate Parity Deviations: is there a Link?," 2020.

Wallen, Jonathan, Markups to financial intermediation in foreign exchange markets, Stanford University, 2020.

Wu, Steve Pak Yeung, "Corporate Balance Sheets and Sovereign Risk Premia," Available at SSRN 3685278, 2020. 
Figure 1: Cash Flow Diagram for Dollar Funding in the Cash and FX Swap Markets

(A) Dollar Funding in the Cash Market

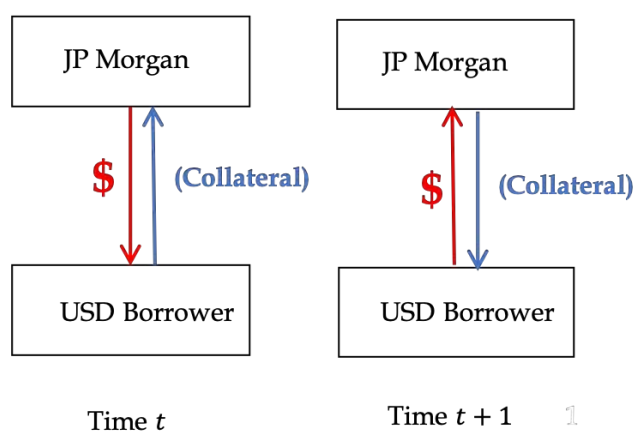

(B) Dollar Funding in the FX Swap Market

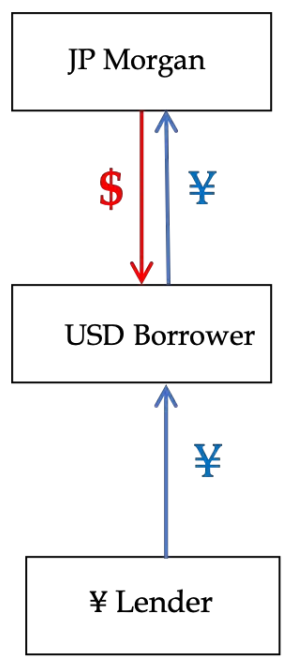

Time $t$

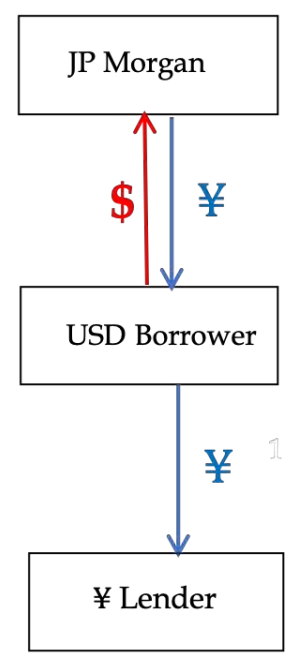

Time $t+1$

Notes: This figure shows a schematic representation of the dollar borrowing in the cash and FX swap market by a USD borrower from a large bank, e.g., JP Morgan. Panel (A) shows dollar funding in the cash market. Panel (B) shows dollar funding in the FX swap market. 
Figure 2: Global Dollar Funding Chains

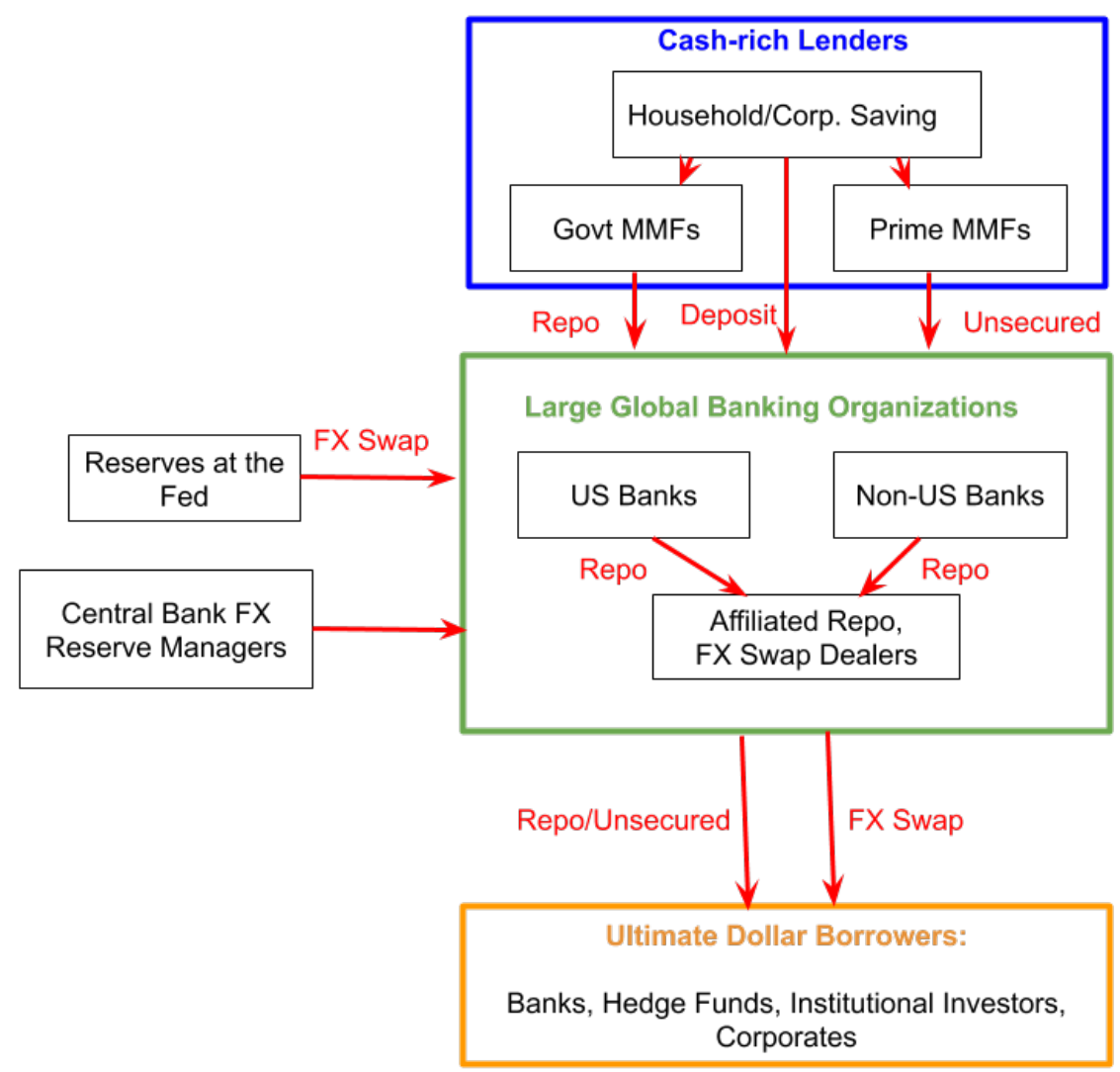

Notes: This figure shows the global dollar funding chains from the cash-rich lenders, like the U.S. MMFs, to the ultimate dollar borrowers. Large global banks play a central role in the intermediation of dollar funding. 
Figure 3: IBOR-CIP Deviations for G10 Currencies vis-à-vis the USD

(A) Three-Month Deviations

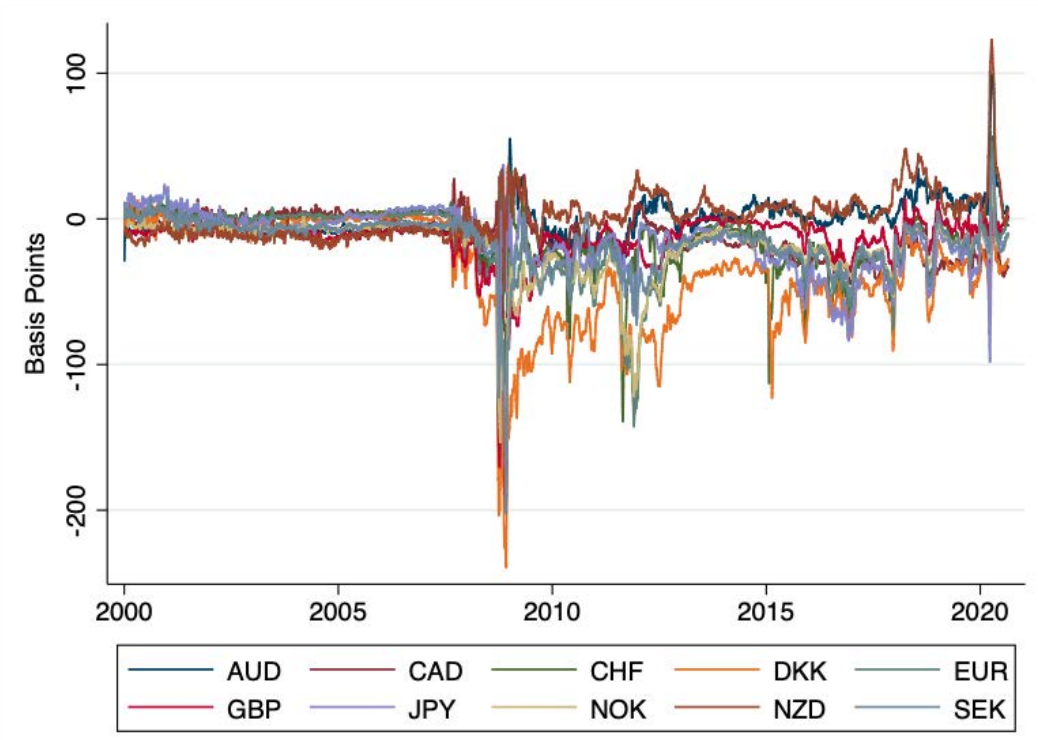

(B) Five-Year Deviations

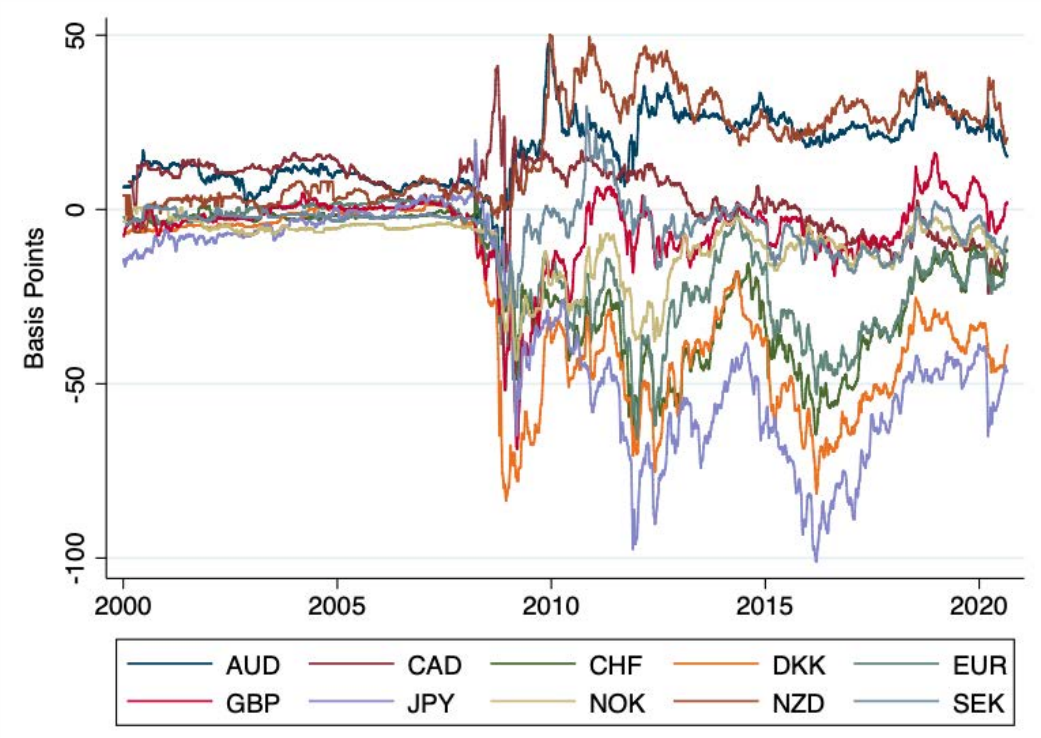

Notes: This figure shows the ten-day moving averages of the three-month (Panel A) and the five-year (Panel B) cross-currency bases based on IBOR. The figure is an updated version of Du, Tepper and Verdelhan (2018a). 
Figure 4: Three-Month Dollar-Yen Cross-Currency Basis for Libor, OIS and Repo Rates

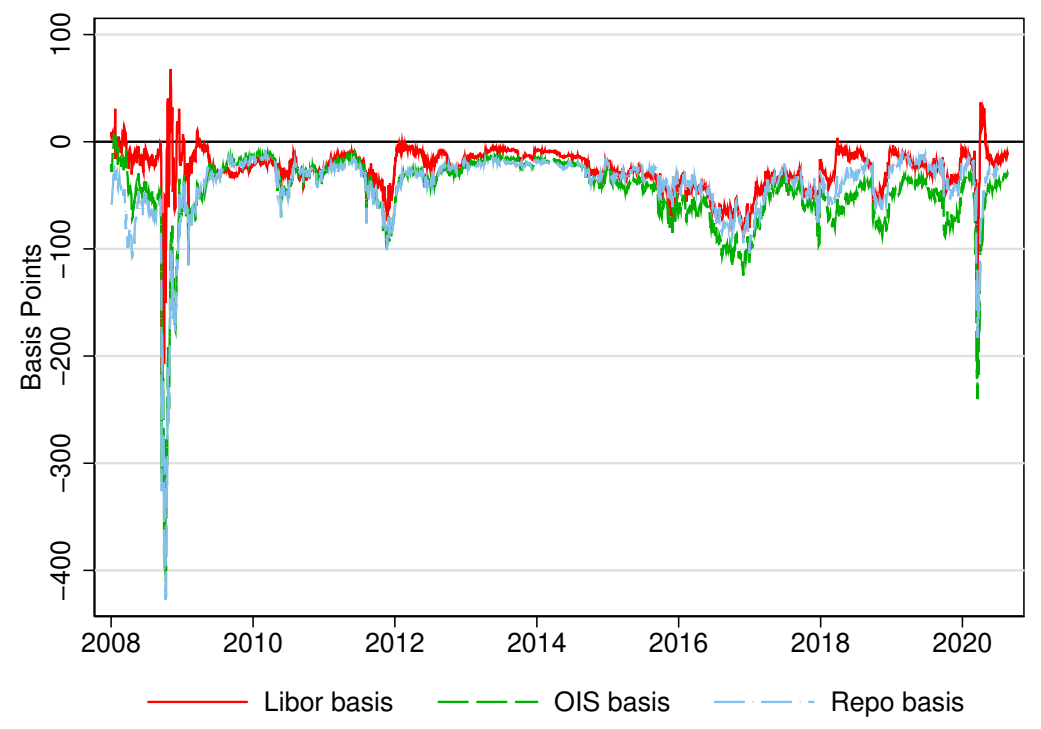

Notes: This figure plots the three-month dollar-yen cross-currency basis for Libor (in red), OIS (in green), and Repo (in blue) rates. 
Figure 5: Cross-Currency Basis and Nominal Interest Rates

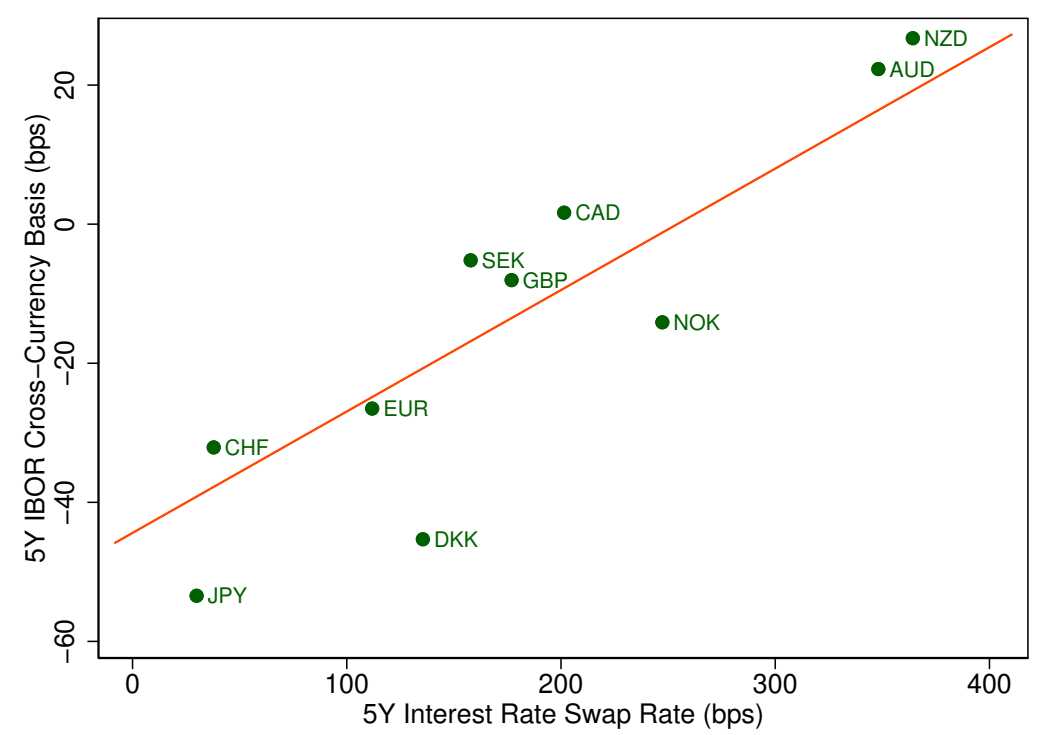

Notes: This figure plots the average five-year IBOR cross-currency basis against the average five-year plain-vanilla interest rate swap rate indexed to IBOR in basis points. The sample period is $01 / 01 / 2008-08 / 21 / 2020$.

Figure 6: Supply and Demand for Dollar Funding in the FX Swap Markets

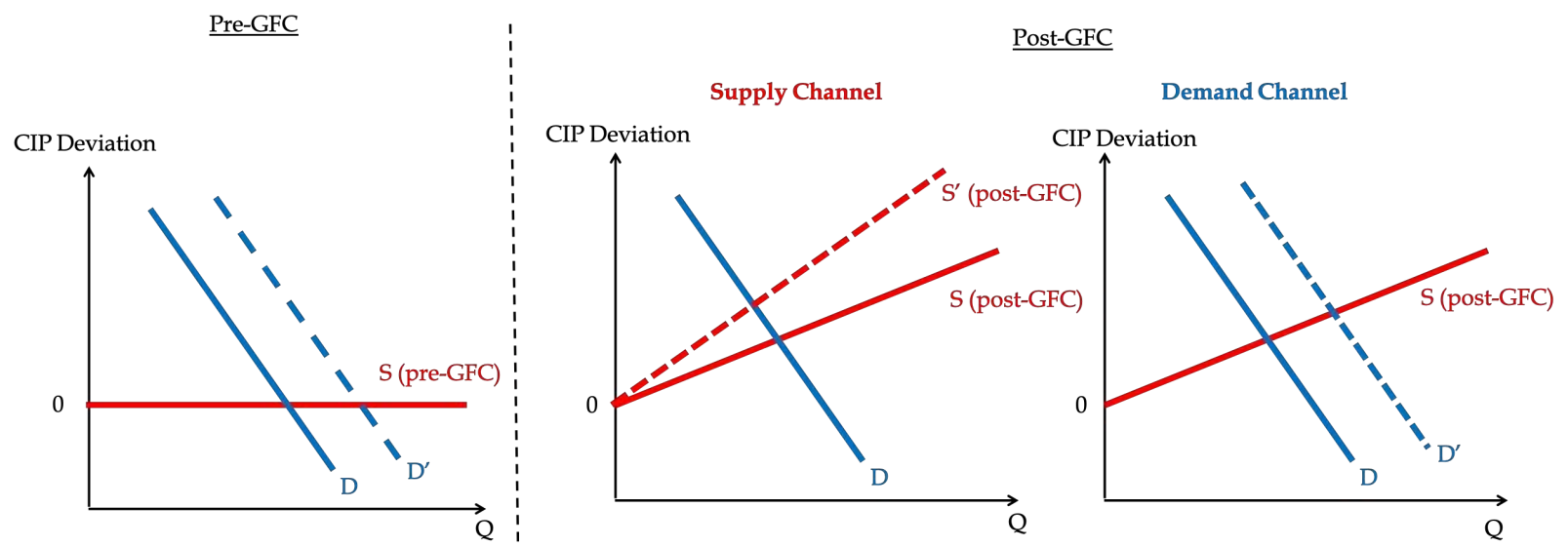

Notes: This figure shows supply and demand diagrams for dollar funding in the FX swap market pre- and post-GFC. The vertical axis shows the the price of FX swap market dollar funding relative to the cash market dollar funding, as measured by the CIP deviation for bank rates. The horizontal axis shows the quantity of dollar funding (and hedging activities). 
Figure 7: Quarter-End Dynamics for 1-Week and 1-Month CIP Deviations

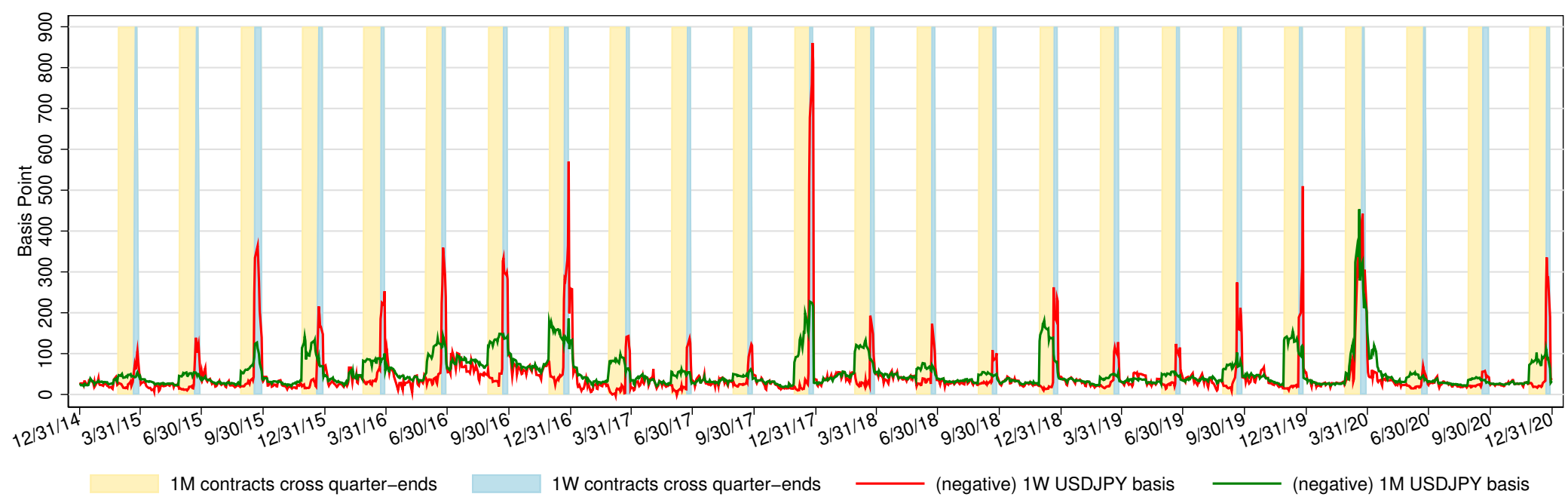

ij Notes: This figure updates the figure in Du, Tepper and Verdelhan (2018a) and plots the one-week and one-month dollar-yen CIP deviations based on the OIS rates in basis points. The light yellow shading denotes trading dates on which the one-month contract shows up on the quarter-end balance sheet, and the light blue shading denotes trading dates on which the one-week contract shows up on the quarter-end balance sheet. 
Figure 8: Overnight CIP Deviations Between Central Bank Deposit Rates

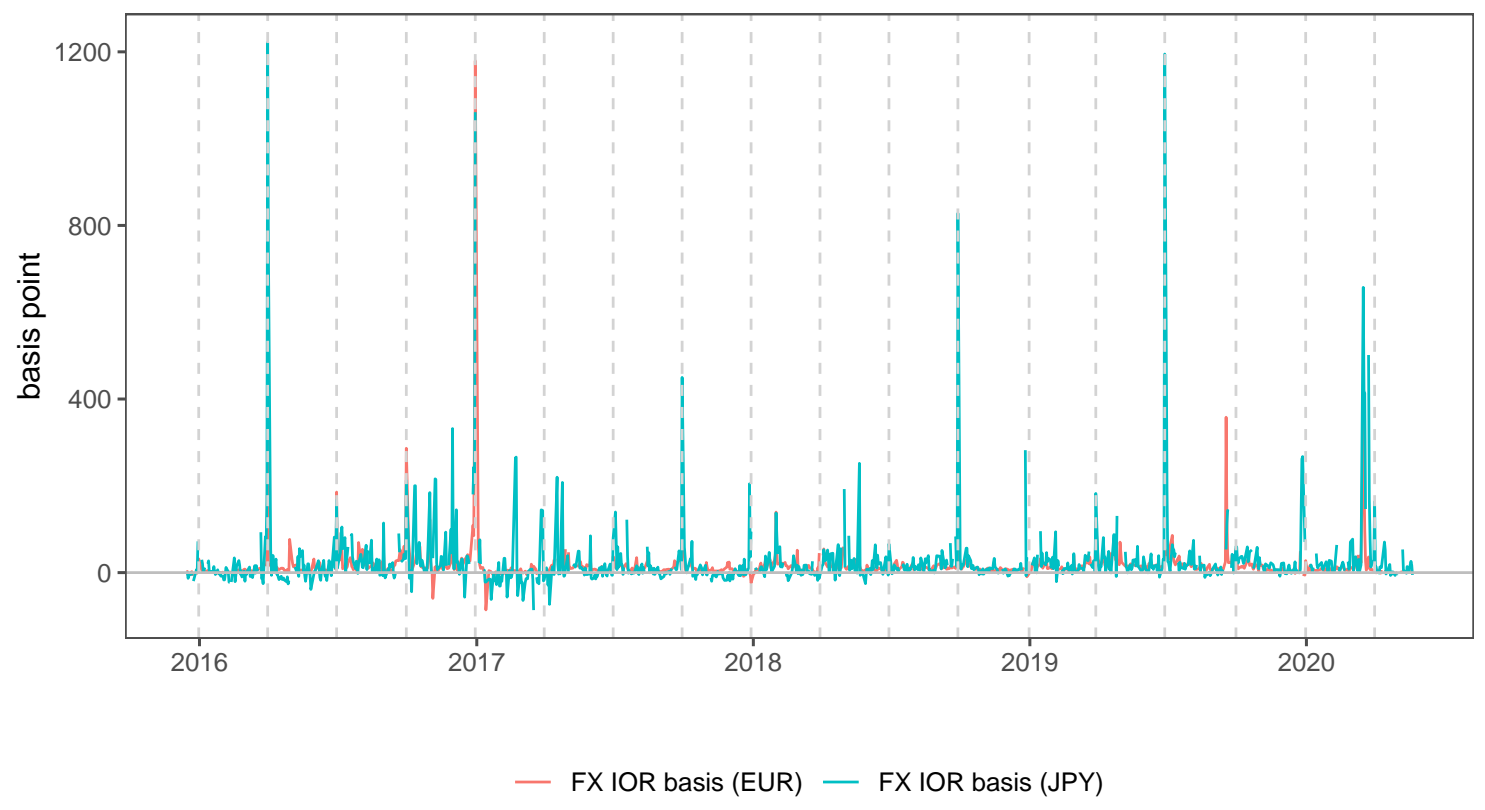

Notes: This figure is reproduced from Correa, Du and Liao (2020) and shows the overnight CIP deviations between interest on excess reserves paid by the Fed and by the ECB/BOJ. "FX IOR Basis (EUR)" is defined as the difference between the swapped ECB deposit rate and the interest on reserves at the Fed. "FX IOR Basis (JPY)" is defined as the difference between the swapped BOJ deposit rate and the interest on reserves at the Fed. The dashed vertical lines denote quarter-ends. 
Figure 9: Correlation Between CIP Deviations and Other Near-Arbitrages

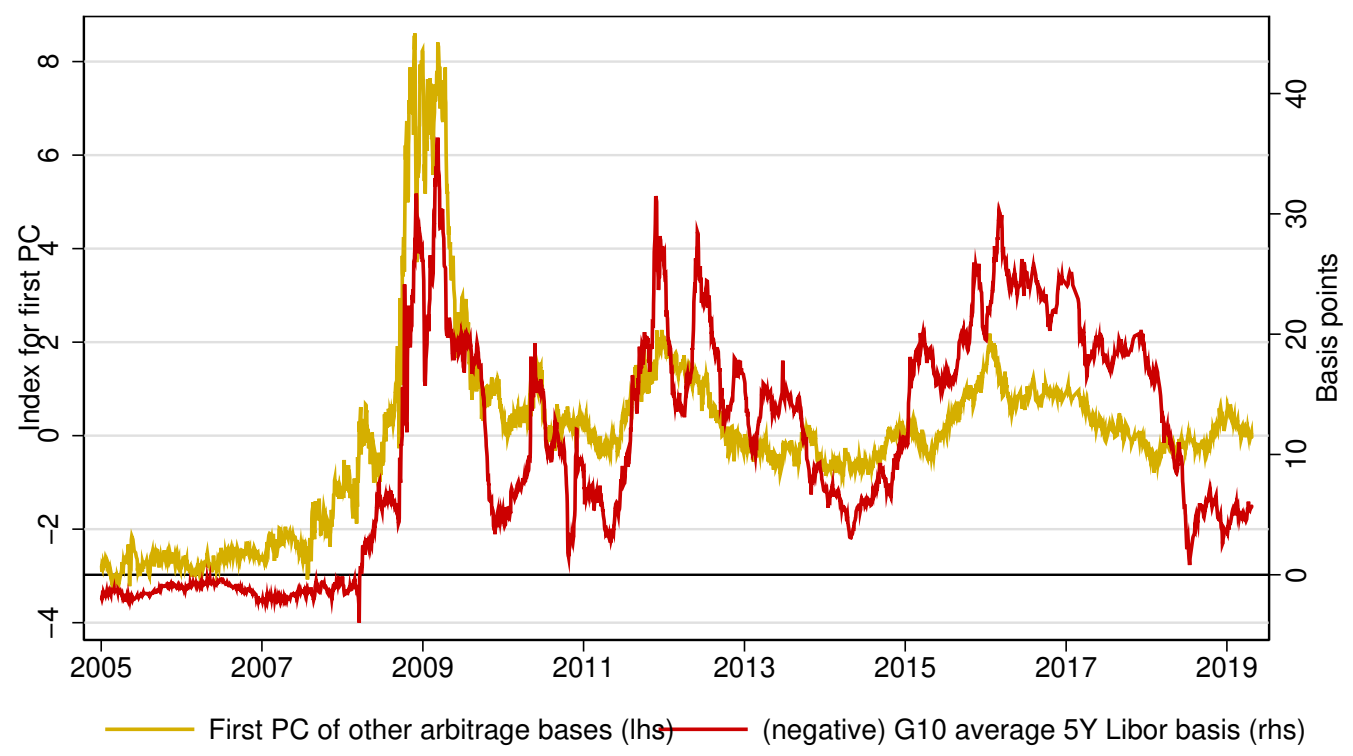

Notes: This is plots the average 5-year Libor cross-currency basis and the first principal component (PC) of seven other near-arbitrages: the bond-CDS basis, the CDS-CDX basis, the U.S. Libor tenor basis, the 30-year Treasury-swap spread, the Refco-Treasury spread, the KfW-Bund spread, and the TIPS-Treasury spread. The construction of the first PC of other arbitrage bases follows Du, Hébert and Huber (2019). 
Figure 10: Corporate Basis and Issuance Flow

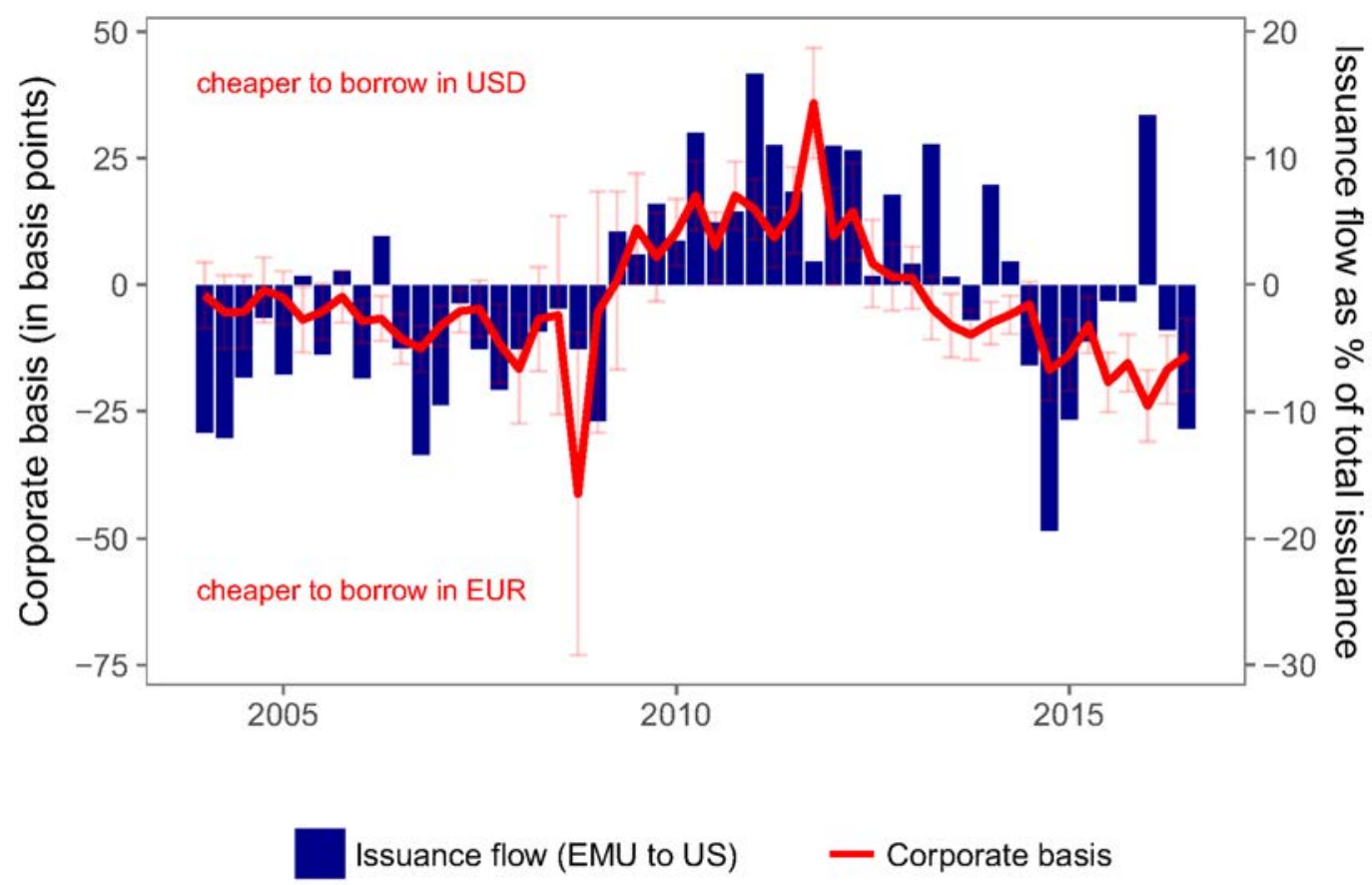

Notes: This figure reproduces Figure 2 in Liao (2020). The figure shows the corporate CIP basis and the bilateral debt issuance flow between the European Monetary Union (EMU) and the US. Issuance flow is measured as the amount of USD debt issued by EMU firms minus the amount of EUR debt issued by U.S. firms scaled by the total amount of debt issuance each quarter. The corporate basis is the estimated differential between the synthetic dollar funding cost by borrowing in EUR and the direct dollar borrowing cost for individual corporate issuers. 
Figure 11: Central Bank Swap Line Outstanding and Rates

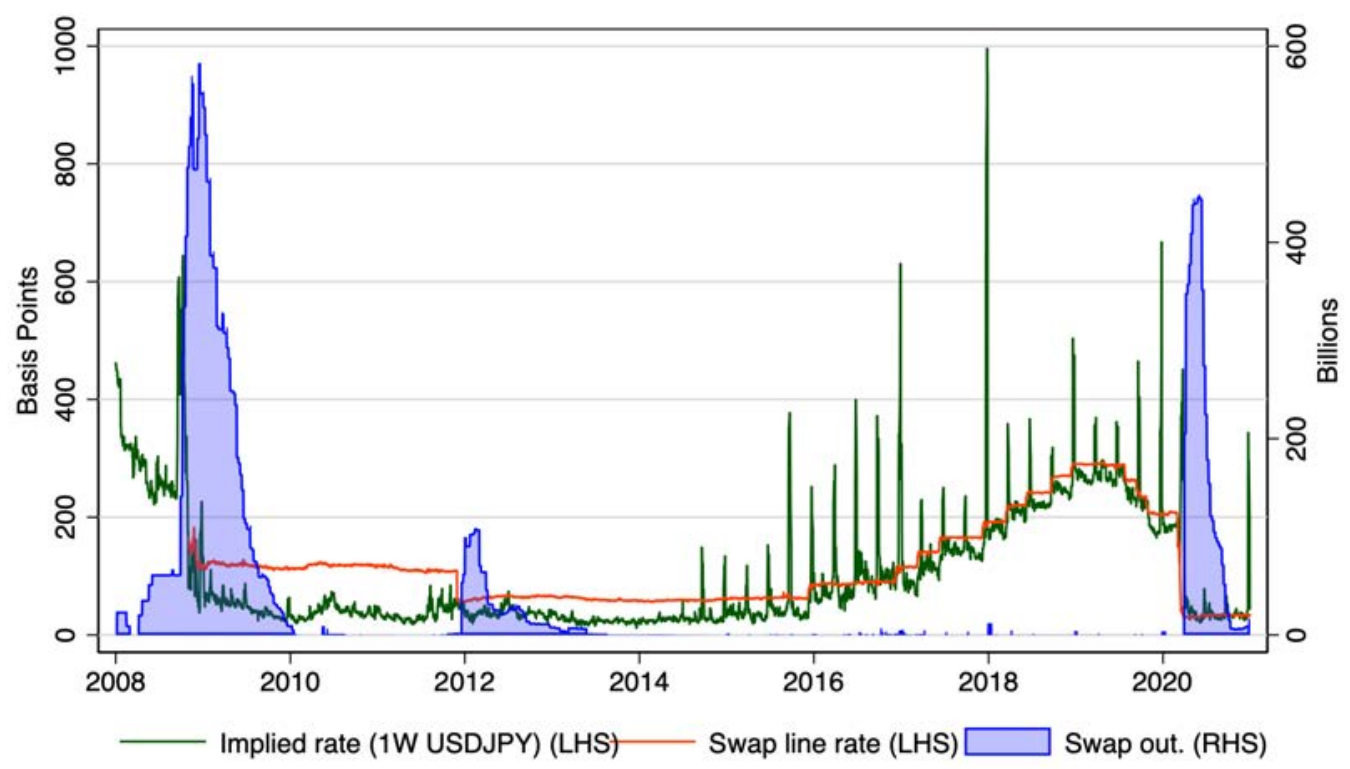

Notes: This figure shows the implied dollar funding rate from the one-week dollar-yen FX swap market, the rate charged by the central bank swap line, and the central swap line outstanding (in USD billions). 
Figure 12: Government Bond CIP Deviations

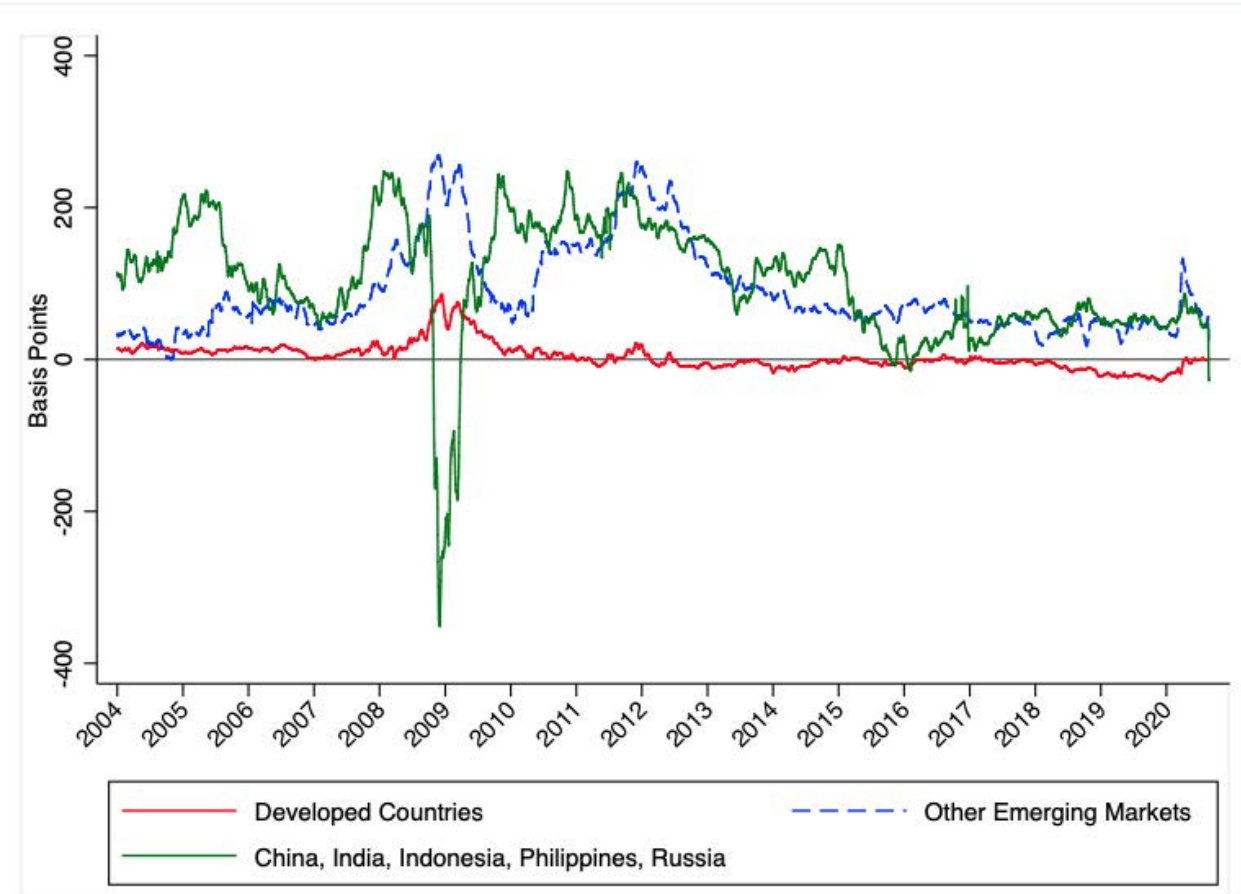

Notes: This figure plots the CIP deviation for 5-year government bonds in "Developed Countries" (Australia, Canada, Switzerland, Denmark, Germany, the United Kingdom, Japan, Norway, New Zealand, and Sweden), "Other Emerging Markets" (Brazil, Chile, Colombia, Hungary, Israel, South Korea, Mexico, Malaysia, Peru, Poland, Thailand, Turkey, and South Africa). 
Figure 13: Term Structure of Government Bond CIP Deviations

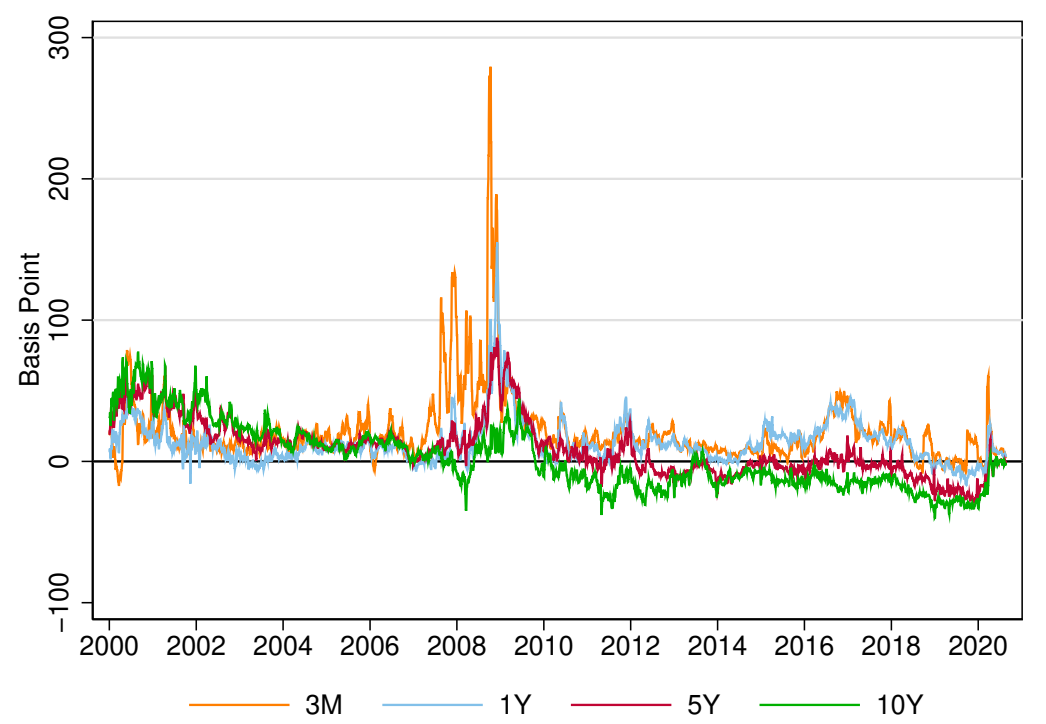

Notes: This figure plots the mean CIP deviation of G10-currency government bonds relative to the U.S. Treasury bonds at the three-month, one-year, five-year and ten-year tenors. The German bund is used for the euro-area sovereign bond. All data are constructed as in Du, Im and Schreger (2018b). One-week moving averages of the series are plotted.

Figure 14: Government Bond vs. Libor CIP Deviations
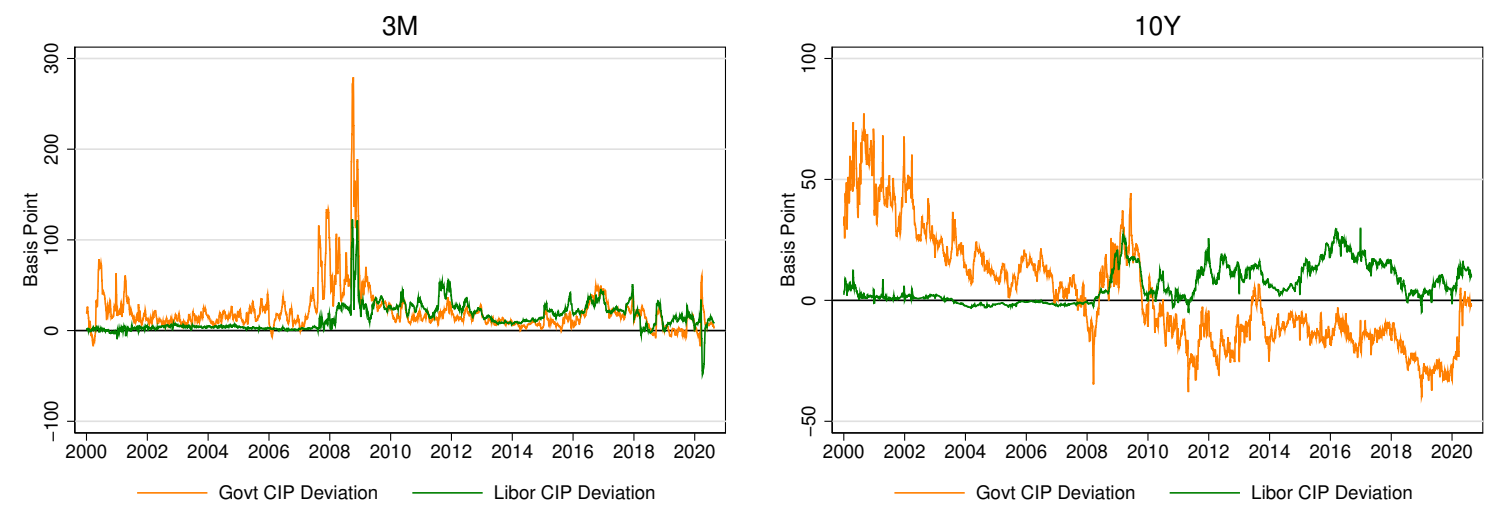

Notes: This figure shows the comparison between the average CIP deviations for G10 currencies and the government bond yields ("Govt CIP deviations") and Libor and interest rate swap rates indexed to Libor ("Libor CIP deviations"). The left panel shows the comparison at the three-month maturity, and the right panel shows the comparison at the 10-year maturity. Both CIP deviations are defined in terms of the difference between the swapped foreign currency yield into dollars (synthetic dollar yield) and the direct dollar yield. One-week moving averages of the series are plotted. 
Figure 15: Emerging Market Government CIP Deviations and CDS Spreads

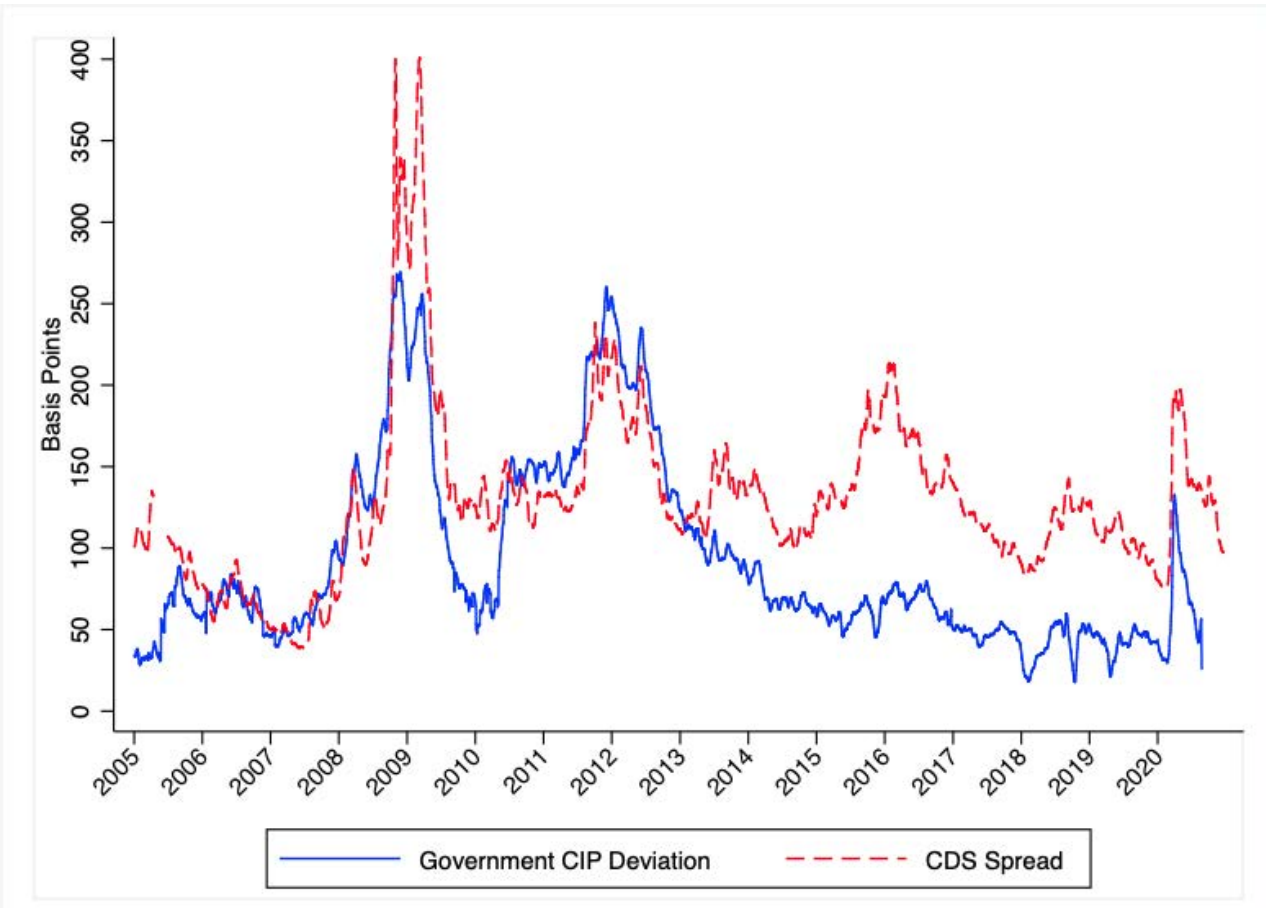

Notes: This figure plots the average CIP deviations relative to U.S. Treasuries at the 5-year tenor for emerging markets and their CDS spreads. Emerging markets consist of Brazil, Chile, Colombia, Hungary, Israel, South Korea, Mexico, Malaysia, Peru, Poland, Thailand, Turkey, and South Africa. 
Table 1: Summary Statistics on Libor CIP Factors

\begin{tabular}{|c|c|c|c|c|c|c|c|c|}
\hline \multirow[b]{2}{*}{ Currency } & \multicolumn{4}{|c|}{ Post-2008 } & \multicolumn{4}{|c|}{ Crisis } \\
\hline & $3 \mathrm{M}$ & $1 \mathrm{Y}$ & $5 \mathrm{Y}$ & $10 \mathrm{Y}$ & $3 \mathrm{M}$ & $1 \mathrm{Y}$ & $5 \mathrm{Y}$ & $10 \mathrm{Y}$ \\
\hline \multirow[t]{2}{*}{ AUD } & 1.7 & 13.2 & 22.3 & 24.0 & 3.6 & 8.2 & 11.1 & 5.1 \\
\hline & $(17.6)$ & $(8.2)$ & $(9.1)$ & $(15.0)$ & $(39.4)$ & $(15.2)$ & (14.8) & $(23.1)$ \\
\hline \multirow[t]{2}{*}{ CAD } & -19.3 & -10 & 1.7 & 5.8 & -9.3 & -1.0 & 7.6 & 9.5 \\
\hline & (14.1) & (12.3) & $(10.5)$ & $(8.9)$ & $(22.2)$ & (16.8) & (17.7) & $(17.3)$ \\
\hline \multirow[t]{2}{*}{$\mathrm{CHF}$} & -23.4 & -25.3 & -32.1 & -35.9 & -30.9 & -31.6 & -31.3 & -29 \\
\hline & $(22.2)$ & (13.8) & (14.9) & (16.7) & $(43.7)$ & (16.8) & (18.2) & (18.6) \\
\hline \multirow[t]{2}{*}{ DKK } & -58.1 & -56.5 & -45.3 & -37.8 & -95.3 & -86.4 & -54 & -35.1 \\
\hline & $(32.4)$ & $(23.5)$ & $(15.9)$ & (14.7) & $(64.8)$ & $(40.2)$ & (16.1) & $(9.8)$ \\
\hline \multirow[t]{2}{*}{ EUR } & -29.6 & -28.2 & -26.5 & -22.3 & -69.3 & -55.5 & -34.5 & -22 \\
\hline & $(25.7)$ & $(17.5)$ & (12.9) & (11.7) & $(54.4)$ & $(29.2)$ & $(15.0)$ & $(9.9)$ \\
\hline \multirow[t]{2}{*}{ GBP } & -16.6 & -10.9 & -8.0 & -7.6 & -43.1 & -23.9 & -13.5 & -10.4 \\
\hline & $(23.3)$ & (14.1) & $(12.2)$ & (11.5) & $(54.2)$ & $(26.2)$ & (13.7) & $(7.2)$ \\
\hline \multirow[t]{2}{*}{ JPY } & -25.4 & -33.3 & -53.4 & -52.8 & -27.3 & -37.7 & -50.8 & -41.7 \\
\hline & (19.3) & $(15.5)$ & $(21.7)$ & $(22.7)$ & $(37.9)$ & (14.0) & $(29.4)$ & $(29.3)$ \\
\hline \multirow[t]{2}{*}{ NOK } & -28.9 & -24.6 & -14.1 & -11.9 & -70.3 & -51.6 & -22.7 & -15.6 \\
\hline & $(23.7)$ & $(16.9)$ & $(9.2)$ & $(7.1)$ & $(48.7)$ & $(30.8)$ & (10.7) & $(6.8)$ \\
\hline \multirow[t]{2}{*}{ NZD } & 9.2 & 16.6 & 26.7 & 33.1 & 23.1 & 18.3 & 22.4 & 23.1 \\
\hline & $(15.5)$ & $(6.9)$ & (11.1) & $(14.2)$ & $(34.8)$ & $(11.9)$ & $(17.5)$ & $(22.5)$ \\
\hline \multirow[t]{2}{*}{ SEK } & -24.8 & -21.3 & -5.2 & 3.7 & -48.9 & -36.8 & -8.7 & -.3 \\
\hline & (19.9) & (13.2) & (8.3) & (9.8) & $(47.3)$ & $(24.0)$ & $(8.6)$ & (10.7) \\
\hline \multirow[t]{2}{*}{ Mean } & -21.4 & -18.3 & -13.7 & -10.5 & -36.5 & -29.8 & -17.7 & -12.1 \\
\hline & $(15.3)$ & $(9.7)$ & $(7.7)$ & $(7.0)$ & $(36.2)$ & $(16.0)$ & $(7.4)$ & $(5.2)$ \\
\hline
\end{tabular}

Notes: This table reports the means and the standard deviations of the daily Libor CIP deviations at the three-month, one-year, five-year, and ten-year horizons. The Post-2008 sample runs from January 1, 2008 to August 27, 2020. The "Crisis" periods are August 2008 - December 2008, November 2011 - February 2012, and March 2020 - May 2020. 
Table 2: Correlation Between First PC of Cross-Currency Basis and Global Risk Factors

\begin{tabular}{lccccccc}
\hline \multicolumn{1}{c}{ Variables } & First PC & Mean Basis & Dollar & VIX & BBB-Tsy & S\&P Ret. & HKM Factor \\
\hline First PC & 1.00 & & & & & & \\
Mean Basis & 0.96 & 1.00 & & & & & \\
Dollar & -0.61 & -0.60 & 1.00 & & & & \\
VIX & -0.33 & -0.33 & 0.55 & 1.00 & & & \\
BBB-Tsy & -0.52 & -0.55 & 0.66 & 0.55 & 1.00 & & \\
S\&P Ret & 0.56 & 0.57 & -0.67 & -0.78 & -0.82 & 1.00 & \\
HKM Factor & 0.62 & 0.62 & -0.42 & -0.35 & -0.79 & 0.74 & 1.00 \\
\hline
\end{tabular}

Notes: This table presents the correlations between the first principal (PC) component of the quarterly changes in the 5-year cross-currency basis of G10 currencies vis-à-vis the U.S. dollar and the quarterly changes in other global risk factors. The variables are as follows: "First PC" denotes the first principal component; "Mean Basis" denotes the quarterly change in the average cross-currency basis across G10 currencies; "Dollar" denotes the quarterly percentage change in the Federal Reserve Board broad dollar index; "VIX" denotes the quarterly percentage change in the implied volatility of the S\&P options; "BBB-Tsy" denotes the quarterly change in the BBB-Treasury spread; "S\&P Ret" denotes the quarterly total return on the S\&P index, and "HKM factor" is the quarterly innovations to the intermediary capital ratio in He, Kelly and Manela (2017). The sample period is 2008Q1-2018Q3. 
Table 3: Quarter-End \& Year-End Jumps in CIP Deviations for Dollar-Yen (Basis Points)

\begin{tabular}{|c|c|c|c|c|c|c|}
\hline \multirow[b]{2}{*}{ Year } & \multicolumn{2}{|c|}{ One-Week Jump } & \multicolumn{2}{|c|}{ One-Month Jump } & \multicolumn{2}{|c|}{ Three-Month Jump } \\
\hline & $\begin{array}{c}(1) \\
\text { 1st QE }\end{array}$ & $\begin{array}{c}(2) \\
\text { All QE }\end{array}$ & $\begin{array}{c}(3) \\
1 \text { st } \mathrm{QE}\end{array}$ & $\begin{array}{c}(4) \\
\text { All QE }\end{array}$ & $\begin{array}{c}(5) \\
\text { 1st YE }\end{array}$ & $\begin{array}{c}\text { (6) } \\
\text { All YE }\end{array}$ \\
\hline 2015 & $\begin{array}{c}128 \\
(68.9)\end{array}$ & $\begin{array}{c}136.5 \\
(82)\end{array}$ & $\begin{array}{c}35.8 \\
(31.2)\end{array}$ & $\begin{array}{c}39.7 \\
(25.8)\end{array}$ & 13.4 & $\begin{array}{c}9.4 \\
.\end{array}$ \\
\hline 2016 & $\begin{array}{c}194.1 \\
(63)\end{array}$ & $\begin{array}{l}237.3 \\
(54.3)\end{array}$ & $\begin{array}{c}51.5 \\
(35.7)\end{array}$ & $\begin{array}{c}63.7 \\
(16.5)\end{array}$ & $\begin{array}{c}14.4 \\
.\end{array}$ & $\begin{array}{c}3.1 \\
.\end{array}$ \\
\hline 2017 & $\begin{array}{c}182 \\
(200.5)\end{array}$ & $\begin{array}{c}245.2 \\
(298.2)\end{array}$ & $\begin{array}{c}37.9 \\
(17.9)\end{array}$ & $\begin{array}{c}53 \\
(50)\end{array}$ & $\begin{array}{c}14.4 \\
.\end{array}$ & $\begin{array}{c}18 \\
.\end{array}$ \\
\hline 2018 & $\begin{array}{l}136.7 \\
(82.4)\end{array}$ & $\begin{array}{c}113 \\
(60.2)\end{array}$ & $\begin{array}{c}50.9 \\
(39.6)\end{array}$ & $\begin{array}{c}52.9 \\
(40.5)\end{array}$ & $\begin{array}{c}32.5 \\
.\end{array}$ & $\begin{array}{c}34.9 \\
.\end{array}$ \\
\hline 2019 & $\begin{array}{c}142.7 \\
(70)\end{array}$ & $\begin{array}{l}144.8 \\
(92.3)\end{array}$ & $\begin{array}{c}43.9 \\
(43.1)\end{array}$ & $\begin{array}{c}46 \\
(40)\end{array}$ & $\begin{array}{c}31 \\
.\end{array}$ & 21.6 \\
\hline 2020 & $\begin{array}{l}104.6 \\
(88.7)\end{array}$ & $\begin{array}{c}81.7 \\
(109)\end{array}$ & $\begin{array}{c}19.7 \\
(16.3)\end{array}$ & $\begin{array}{c}63.9 \\
(73.7)\end{array}$ & $\begin{array}{c}15.8 \\
.\end{array}$ & 13.8 \\
\hline Total & $\begin{array}{c}148 \\
(99.6) \\
24\end{array}$ & $\begin{array}{c}159.7 \\
(141) \\
24\end{array}$ & $\begin{array}{c}39.9 \\
(30.6) \\
24\end{array}$ & $\begin{array}{c}53.2 \\
(40.7) \\
24\end{array}$ & $\begin{array}{c}20.3 \\
(8.9) \\
6\end{array}$ & $\begin{array}{c}16.8 \\
(11) \\
6\end{array}$ \\
\hline
\end{tabular}

Notes: This table reports the mean and the standard deviations of the quarter(year)-end jumps in dollar-yen CIP deviations based on the OIS rates by year. Column 1 summarizes the one-day jump in the 1-week CIP deviation on the first quarter-end crossing (QE) date for each quarter relative to the average 1-week CIP deviation across the five business days prior to the first $\mathrm{QE}$ date. Column 2 summarizes the average quarter-end jump in the 1-week CIP deviation across all trading dates that cross the quarter-end, relative to the average 1-week CIP deviation across the five business days prior to the first QE date. Columns 3 and 4 repeat the exercise to summarize the one-day and average quarter-end effect for the one-month CIP deviations. Columns 5 and 6 summarize the one-day and average year-end (YE) effect for the three-month CIP deviations. 
Table 4: The Broad Dollar and Mean CIP Deviations

\begin{tabular}{llcccc}
\hline & & $3 \mathrm{~m}$ & $1 \mathrm{y}$ & $5 \mathrm{y}$ & $10 \mathrm{y}$ \\
\hline Libor Mean USD & $\beta$ & -0.01 & $-0.17^{* * *}$ & $-0.42^{* * *}$ & $-0.44^{* * *}$ \\
& & $(0.03)$ & $(0.06)$ & $(0.09)$ & $(0.11)$ \\
& $R^{2}$ & 0.01 & 0.14 & 0.30 & 0.25 \\
& $N$ & 50 & 50 & 50 & 50 \\
\hline \multirow{3}{*}{ Govt Mean USD } & $\beta$ & -0.01 & $-0.15^{* * *}$ & $-0.18^{* * *}$ & $-0.14^{* *}$ \\
& & $(0.02)$ & $(0.03)$ & $(0.06)$ & $(0.06)$ \\
& $R^{2}$ & 0.03 & 0.32 & 0.18 & 0.08 \\
& $N$ & 50 & 47 & 50 & 44 \\
\hline
\end{tabular}

Notes: The table reports regressions of the form

$$
\Delta e_{t}^{\$}=\alpha+\beta \Delta \bar{x}_{t}+\epsilon_{t} .
$$

The dependent variable in all regressions is the quarterly change in log broad dollar exchange rate. The column heading denotes the tenor of the CIP deviation, "3m" for three-month, "1y" for one-year, "5y" for five-year, and "10y" for ten-year. The Libor Mean USD is the quarterly change in the average Libor CIP deviation against the USD and the Govt Mean USD is the mean Government Bond CIP deviation against the USD. All variables are constructed as in Du, Im and Schreger (2018b). Significance levels are denoted by *** $p<0.01,{ }^{* *} p<0.05$, and ${ }^{*} p<0.1$. 
Table 5: Bilateral Exchange Rate Against the USD

\begin{tabular}{|c|c|c|c|c|c|c|c|c|c|c|c|c|}
\hline & & Pooled & AUD & CAD & $\mathrm{CHF}$ & DKK & EUR & GBP & JPY & NOK & NZD & SEK \\
\hline \multicolumn{13}{|l|}{ One-Year Tenor } \\
\hline \multirow[t]{2}{*}{ Libor Mean USD } & $\beta$ & $-0.19^{* * *}$ & $-0.26^{* *}$ & -0.08 & $-0.21^{* * *}$ & $-0.25^{* * *}$ & $-0.25^{* * *}$ & $-0.17^{*}$ & 0.03 & $-0.23^{* *}$ & $-0.18^{*}$ & $-0.25^{* * *}$ \\
\hline & $R^{2}$ & 0.10 & 0.13 & 0.03 & 0.18 & 0.23 & 0.23 & 0.09 & 0.00 & 0.10 & 0.07 & 0.16 \\
\hline \multirow[t]{2}{*}{ Govt Mean USD } & $\beta$ & $-0.15^{* * *}$ & $-0.26^{* * *}$ & $-0.11^{* * *}$ & $-0.12^{* * *}$ & $-0.16^{* * *}$ & $-0.16^{* * *}$ & $-0.14^{* * *}$ & 0.04 & $-0.22^{* * *}$ & $-0.21^{* * *}$ & $-0.21^{* * *}$ \\
\hline & $R^{2}$ & 0.19 & 0.34 & 0.14 & 0.17 & 0.27 & 0.28 & 0.19 & 0.01 & 0.27 & 0.27 & 0.31 \\
\hline \multirow[t]{2}{*}{ Bilateral Libor } & $\beta$ & $-0.08^{* * *}$ & 0.22 & -0.08 & $-0.12^{* * *}$ & $-0.10 *$ & $-0.10^{* * *}$ & -0.03 & -0.03 & $-0.19 * * *$ & $0.26^{* *}$ & $-0.18^{*}$ \\
\hline & $R^{2}$ & 0.04 & 0.06 & 0.01 & 0.16 & 0.11 & 0.20 & 0.01 & 0.00 & 0.16 & 0.10 & 0.13 \\
\hline \multirow[t]{2}{*}{ Bilateral Govt } & $\beta$ & $-0.08 * * *$ & $-0.11^{*}$ & $-0.15^{* * *}$ & -0.05 & -0.08 & $-0.11^{* * *}$ & 0.00 & -0.01 & $-0.14^{* * *}$ & $-0.14^{* * *}$ & $-0.09 *$ \\
\hline & $R^{2}$ & 0.09 & 0.09 & 0.23 & 0.09 & 0.10 & 0.20 & 0.00 & 0.00 & 0.31 & 0.17 & 0.16 \\
\hline \multicolumn{13}{|l|}{ Five-Year Tenor } \\
\hline \multirow[t]{2}{*}{ Libor Mean USD } & $\beta$ & $-0.42^{* * *}$ & $-0.58^{* * *}$ & $-0.39^{* * *}$ & $-0.27^{* *}$ & $-0.42^{* * *}$ & $-0.42^{* * *}$ & $-0.56^{* * *}$ & 0.15 & $-0.62^{* * *}$ & $-0.57^{* * *}$ & $-0.56^{* * *}$ \\
\hline & $R^{2}$ & 0.19 & 0.23 & 0.25 & 0.12 & 0.23 & 0.24 & 0.37 & 0.02 & 0.29 & 0.27 & 0.30 \\
\hline \multirow[t]{2}{*}{ Govt Mean USD } & $\beta$ & $-0.18 * * *$ & $-0.26 * *$ & $-0.15^{* *}$ & $-0.13^{* *}$ & $-0.17^{* * *}$ & $-0.17 * * *$ & $-0.20 * * *$ & 0.04 & $-0.22^{* *}$ & $-0.29 * * *$ & $-0.27^{* * *}$ \\
\hline & $R^{2}$ & 0.10 & 0.14 & 0.12 & 0.08 & 0.12 & 0.12 & 0.14 & 0.00 & 0.11 & 0.21 & 0.20 \\
\hline \multirow[t]{2}{*}{ Bilateral Libor } & $\beta$ & $-0.17 * * *$ & -0.08 & $-0.17 * *$ & $-0.21^{* * *}$ & $-0.11^{* *}$ & $-0.24^{* * *}$ & $-0.38 * * *$ & -0.05 & $-0.43^{* * *}$ & 0.01 & $-0.52 * * *$ \\
\hline & $R^{2}$ & 0.08 & 0.01 & 0.12 & 0.17 & 0.09 & 0.27 & 0.27 & 0.01 & 0.18 & 0.00 & 0.27 \\
\hline \multirow[t]{2}{*}{ Bilateral Govt } & $\beta$ & $-0.10^{* * *}$ & -0.04 & $-0.13^{* * *}$ & $-0.11^{* * *}$ & -0.04 & $-0.07^{*}$ & $-0.12^{* *}$ & -0.05 & $-0.17^{* * *}$ & $-0.16^{* * *}$ & -0.07 \\
\hline & $R^{2}$ & 0.07 & 0.01 & 0.23 & 0.13 & 0.01 & 0.05 & 0.11 & 0.02 & 0.18 & 0.14 & 0.03 \\
\hline
\end{tabular}

Notes: The table reports regressions of the form

$$
\Delta e_{t}^{i / \$}=\alpha_{i}+\beta_{i} \Delta x_{i, t}+\epsilon_{i, t}
$$

The dependent variable in all regressions is the quarterly change in the bilateral exchange rate against the USD. The column heading denotes the currencies, and "Pooled" indicates all currencies were pooled in a single panel regression. The Libor Mean USD is the quarterly change in the average Libor CIP deviation against the USD and the Govt Mean USD is the mean Government Bond CIP deviation against the USD. Bilateral Libor is the currency-specific Libor-based CIP deviation against the USD and Bilateral Govt is the bilateral CIP deviation between the government bond yield in that particular currency and US Treasuries. All variables are constructed as in Du, Im and Schreger (2018b). Significance levels are denoted by $* * *$ $p<0.01,{ }^{* *} p<0.05$, and ${ }^{*} p<0.1$. 


\section{Appendix}

\section{A Calculating the Annualized Forward Premium}

In this section, we describe the calculation method for the FX forward premium for various maturities. To be precise, we let $t$ denote the trade date, $t_{s}$ denotes the spot settlement date, which is typically two business days after the trade date, ${ }^{34}$ and $t_{m}$ denotes the maturity date of the forward transaction. Depending on the time between the trade date and the maturity date, we have different calculation methods for the forward premium.

First, if the maturity date is within one-year after the spot settlement date, i.e., $0<$ $t_{m}-t_{s}<1$, we calculate the FX premium from the spot and forward exchange rates. In particular,

$$
\rho_{t_{0}, t_{m}}=\frac{360}{A C T\left(t_{s}, t_{m}\right)} \frac{\Phi_{t, t_{m}}}{S_{t}}
$$

where $A C T\left(t_{s}, t_{m}\right)$ denotes the number of calendar days between the spot settlement date $t_{s}{ }^{35}$ and the forward settlement date $t_{m}$, and $\Phi_{t, t_{m}}=F_{t, t_{m}}-S_{t}$ is the forward point for forward contract traded at $t$ and maturing at $t_{m}$.

Second, if the maturity date is greater than one year away from the spot settlement date, FX forward market becomes illiquid at these longer maturities. Instead, we can calculate the long-term forward premium based on the fixed-for-fixed cross-currency swaps. ${ }^{36}$ As discussed in Du and Schreger (2016) and Du, Tepper and Verdelhan (2018a), for developed market currencies, the fixed-for-fixed cross-currency swap rate can be constructed in three steps. First, we pay the fixed-for-floating interest rate swap, $r_{t, t+n}^{i, I R S}$, in order to swap the fixed interest rate in currency $i$, for a floating benchmark interest rate in currency $i$. At

\footnotetext{
${ }^{34}$ The notable exception is the Canadian dollar, for which the spot settlement date is 1 business day after the trade date.

${ }^{35}$ The annualization factor for foreign exchange forward rates is generally $360 / A C T$. The British pound is an exception, for which the annualization factor is $365 / A C T$.

${ }^{36}$ We provide Bloomberg tickers to construct the long-term forward premium for major developed and emerging market currencies in the internet appendix for Du, Im and Schreger (2018b). An updated dataset used to measure CIP throughout this chapter is available for download here.
} 
this point, we are still in the same currency, but only swapped the fixed interest rate to get a floating rate. Second, we pay the cross-currency basis swap, $x c c y_{t, t+n}^{i / \$}$, to swap the floating benchmark in currency $i$ for a floating benchmark in the dollar, i.e., the U.S. Libor. Third, we swap the U.S. Libor back to a fixed dollar interest rate, so, we receive the U.S. fixed-for-floating interest rate swap, i.e., $r_{t, t+n}^{\$, I R S}$. By combining these three steps, we are able to swap a fixed foreign currency interest rate for a fixed dollar interest rate. The expression for the long-term forward premium is therefore given by:

$$
\rho_{t, t+n}^{i / \$}=r_{t, t+n}^{i, I R S}+x c c y_{t, t+n}^{i / \$}-r_{t, t+n}^{\$, I R S}
$$

Comparing this expression to equation 1, we see that the cross-currency basis swap rate $x c c y_{t, t+n}^{i / \$}$ directly measures the long-term deviations from CIP for IBOR-indexed interest rate swap rates.

For many emerging market currencies, the first two steps of the swaps are combined into a single instrument. We let $r_{t, t+n}^{i / \$, N D S}$ denote a non-deliverable cross-currency swap that swaps the fixed interest rate in currency $i$ for U.S. Libor, such that we have:

$$
\rho_{t, t+n}^{i / \$}=r_{t, t+n}^{i / \$, N D S}-r_{t, t+n}^{\$, I R S}
$$

Third, if the maturity date is actually before the spot settlement date, we need to adjust the formulas. The complication is that the spot exchange rate refers to the exchange rate on the spot settlement date, two business days away from the trade date. There are two important short-dated FX swap contracts that mature before the spot settlement date. In an overnight (ON) FX swap, the near leg of the swap settles on trade date, whereas the far leg settles on the next business date. In a tomorrow-next (TN) FX swap, the near leg of the swap settles on the next business date after the trade, and the far leg of the swap settles on the spot settlement date. We let the forward point associated with the ON and TN swaps be $\Phi_{t}^{o n}=F_{t, t}-F_{t, t_{o n}}$ and $\Phi_{t}^{t n}=S_{t}-F_{t, t_{t n}}$, respectively. Therefore, we have the ON forward 
premium equal to

$$
\rho_{t}^{O N}=\frac{360}{A C T\left(t, t_{o n}\right)}\left(\frac{\Phi_{t}^{o n}}{S_{t}-\Phi_{t}^{t n}-\Phi_{t}^{o n}}\right),
$$

and the $\mathrm{TN}$ forward premium is equal to

$$
\rho_{t}^{T N}=\frac{360}{A C T\left(t_{o n}, t_{t n}\right)}\left(\frac{\Phi_{t}^{t n}}{S_{t}-\Phi_{t}^{t n}}\right) .
$$

